\title{
Drug Dosing during Pregnancy- Opportunities for Physiologically Based Pharmacokinetic Models
}

\author{
Khaled Abduljalil $^{1}$, Raj K. Singh Badhan ${ }^{2}$ \\ ${ }^{1}$ Certara UK Limited (Simcyp), Level 2-Acero, 1 Concourse Way, Sheffield S1 2BJ, UK \\ ${ }^{2}$ Aston Pharmacy School, Aston University, Birmingham, B4 7ET, UK
}

\section{Correspondence}

Khaled Abduljalil

Certara UK Limited, Simcyp Division,

Level 2-Acero, 1 Concourse Way,

Sheffield,

S1 2BJ

United Kingdom

Tel +44(0) 1144600150

Fax +44(0) 1144785600

E-mail: khaled.abduljalil@certara.com 


\begin{abstract}
Drugs can have harmful effects on the embryo or fetus at any point during pregnancy. Not all the damaging effects of intrauterine exposure to drugs are obvious at birth, some may only manifest later in life. Thus, drugs should be prescribed in pregnancy only if the expected benefit to the mother is thought to be greater than the risk to the fetus. Dosing of drugs during pregnancy is often empirically determined and based upon evidence from studies of nonpregnant subjects, which may lead to suboptimal dosing, particularly during the third trimester.

This review collates examples of drugs with known recommendations for dose adjustment during pregnancy, in addition to providing an example of the potential use of PBPK models in dose adjustment recommendation during pregnancy within the context of drug-drug interactions.

For many drugs, such as antidepressants and antiretroviral drugs, dose adjustment has been recommended based on pharmacokinetic studies demonstrating a reduction in drug concentrations. However, there is relatively limited (and sometimes inconsistent) information regarding the clinical impact of these pharmacokinetic changes during pregnancy and the effect of subsequent dose adjustments. Three examples were described to show how pregnancy PBPK can facilitate and guide dose assessment throughout gestation.
\end{abstract}

\title{
Keywords
}

Pregnancy, Physiologically-based pharmacokinetic model, Dosing adjustmentFetal exposure 


\section{Background}

Pharmacotherapy plays a major role in obstetrical care throughout pregnancy. The total avoidance of pharmacological treatments is often not feasible as pregnant women frequently require therapeutic intervention for pregnancy-related conditions and those unrelated to their pregnancies that require ongoing or episodic treatment (e.g., asthma, epilepsy, hypertension). Such pharmacotherapy requires knowledge of the proper dosing in order to achieve the appropriate drug concentrations for efficacious management of the condition and to prevent poor fetal outcomes associated with poor maternal disease control. However, there are still vast gaps in pharmacology information and evidence for appropriate dosing of medications in pregnant women $[1,2]$. The rates of prescription drug use in pregnancy, excluding prenatal vitamins, were reported to be about $44 \%$ in Denmark and Finland, $85 \%$ in Germany and 93\% in France [3]. The frequency of using these prescription drugs during pregnancy is higher during first trimester as many women may not be aware of their pregnancy during this time, but also during the third trimester due to the development of new gestational-related conditions, amplifying of underlying pre-pregnancy conditions or preparation for caesarean section. It is also intuitive to minimize drug exposure or intake during early gestational weeks, when the teratogenic window is at its highest sensitivity.

Currently, there is a paucity in data for prescribers and patients to make informed decisions as to the proper selection and appropriate dosing of many drugs used during pregnancy [4]. Many drug labels advise not to take these drugs due to absence of safety data. Despite these warnings, many older drugs, due to their long history of use and track record of safety profiles in non-pregnant patients, are prescribed off-label. A review of surveys among developed countries indicated that the percentages of use of contraindicated medicines in pregnancy ranged from around $1 \%$ in Denmark to 5\% in USA, while the percentage of use of overall harmful drugs ranged from $2 \%$ in Italy to $59 \%$ in France [3]. In a UK study, about $24 \%$ of drugs prescribed to pregnant women were off-label and $16 \%$ were of high risk [5]. In a French study, about $28 \%$ of drugs prescribed to pregnant women were offlabel; $22 \%$ were considered high-risk, and $7 \%$ were contraindicated medications [6]. Likewise in the USA, about $23 \%$ of pregnant patients received at least one off-label drug. When prescriptions were grouped per trimester, about $94 \%$ of these prescriptions were during the third trimester [7]. It should however, be pointed out that unlicensed or off-label use may be necessary if the clinical need cannot be met by licensed medicines; such use should be supported by appropriate evidence and experience as it increases the prescriber's professional responsibility and potential liability. Unfortunately, the recommended doses and dosing intervals for off-label drugs may be inaccurate because they are based on the pharmacokinetics usually determined in healthy "male" volunteers. However, it is worth nothing that clinical practice habits and labelling can differ between countries; for example, doxylamine is off-label and seldom used in France but is on-label in the USA for nausea/vomiting during pregnancy (see [6]).

\section{Challenges in dosing pregnant patients}

Historically, pregnant women are actively excluded from drug development clinical trials, and, if pregnancy does occur, the usual procedure is to discontinue treatment and remove the patient from the study. Such challenges have led to the status quo that the number of medicinal products currently labelled for use during pregnancy is 
limited, which translates into current clinical practice which results in doses for pregnant women being based upon adult doses. Pregnant women, however, do not exhibit pharmacokinetics of typical subjects recruited onto clinical trials, and often pregnancy results in the processing of medications differently to that of men [8,9]. This difference is a result of well-known physiological changes that take place during pregnancy [10], such as differences in enzyme activities, cardiac output, tissue blood flow, renal function, body fluids and development of new feto-placental unit (Figure 1). These factors limit our ability to establish safe and effective doses for pregnant patients, making the establishment of safe and efficacious doses based on data obtained under different physiological statuses difficult. This is primarily manifested through the impact on numerous pharmacokinetic processes, such as drug metabolism, increasing distribution volume, and addition of the growing feto-placental unit $[11,8]$.

For drugs with a narrow therapeutic window, an increased clearance during pregnancy can lead to sub-therapeutic concentrations and worsening disease control. Ideally, pregnant patients should receive drugs that have been appropriately evaluated for their use in this population. In 2004, the US Food and Drug Administration (FDA) released a guidance describing a framework for designing and conducting PK/PD studies in pregnant women with recommendations on how to assess the influence of pregnancy on drugs PK/PD and what to consider when designing and conducting PK studies in pregnant women [12]. The FDA has also increased pregnancy investigation requirements and has given recommendations on how and when to include pregnant women in drug development clinical trials [13]. Furthermore, FDA replaced the pregnancy categories letters from all human prescription drug and biological product labels with meaningful information about the risks of using a drug during pregnancy [14]. The gestational age dependency in PK/PD may require direct investigations through clinical studies, or indirect investigations through the application of a model-based approach.

\section{The role of physiologically-based pharmacokinetic models}

The combined effects of multiple physiological parameters during pregnancy on drug kinetics can be augmented or partially/totally cancel each other out. For example, the reduction in albumin concentration and the increasing in CYP3A4 activity, together with the rise in cardiac output during pregnancy (Figure 1) has led to increased midazolam clearance [15], a drug that is normally classified as intermediate hepatic extraction ratio in adult healthy volunteers. The increasing clearance with gestational age can easily push this compound to high extraction ratio region during the third trimester, a situation that has been seen in the paediatric population [16]. Such increases in clearance during pregnancy, together with the increasing volume of distribution (Figure 1), should result in lower drug exposure in pregnant women compared with their non-pregnant counterparts and hence higher doses are required to achieve similar exposure [17].

Pregnancy can increase the distribution volume of drugs to different levels depending on the stage of pregnancy and the physico-chemical properties of the drug. Physiological parameters include, but not limited to, changes in the level of binding proteins, expansion of intravascular fluid, accumulation of fat, growth of the feto-placental organs, composition of different organs, changes to the blood flow and induction of transporter expressions. Expansion of plasma volume can increase distribution volume and lower the peak and steady-state concentrations of hydrophilic drugs if the dosing is unchanged [18]. Reduction in plasma binding protein can increase the free 
fraction of highly protein-bound drugs such as midazolam, valproic acid and phenytoin and increase their distribution to the extravascular space. Current pregnancy PBPK models integrate such physiological changes with physico-chemical properties of the drug such as lipophilicity, changes in drug free fraction, affinity to cellular components and transporter kinetics, to describe the change to the drug distribution volume during pregnancy and partitioning into different tissues using different predictive methods $[19,20]$.

A unique situation during pregnancy is the induction of CYP2D6 resulting in depletion of CYP2D6 substrates such as, dextromethorphan [21], paroxetine [22] and metoprolol [23] from the plasma of pregnant women, who are extensive and ultra-rapid CYP2D6 metabolizers. Depending on whether the parent drug or the metabolite is the pharmacologically active substance, differences in genotype can have different effects on maternal plasma concentrations of the active drugs during pregnancy, leading to therapeutic and safety consequences. In addition, the activity of CYP1A2 decreases as a function of gestational age [24] along with an increase in CYP2D6 activity. Together these phenomena can partially cancel the effect of each other on drug metabolism, as demonstrated by the relatively consistent systemic exposure for propranolol during pregnancy [25]. However, this also depends on the contribution of these enzymes to the overall clearance, for example if the subject is an ultra-rapid metabolizer with respect to CYP2D6, then the impact of CYP2D6 on propranolol clearance will be dominant and dose increase may be required. Conversely, CYP1A2 is the dominant metabolizing enzyme for theophylline clearance in nonpregnant subjects, but toward the end of pregnancy this can lead to a decreasing metabolic clearance increased exposure. This has been observed in two of six pregnant women at third trimester [26] and required dose reduction. The fact that not all patients did not require dose reduction can be attributed to the increasing compensatory effect of renal clearance with gestational age. Therefore, pregnancy partially converts a proportion of theophylline clearance from hepatic metabolic clearance to renal with advancing gestational time. Due to such a dynamic nature during pregnancy, the implementation of pregnancy physiologically based pharmacokinetic (PBPK) models catering for such physiological changes and their mutual effects with pharmacokinetic processes, is a necessary step in maternal drug development and therapeutics.

\section{Pharmacogenomics-bases dosing strategy}

Over the last few years, there has been a substantial rise in the number of new drugs that carry pharmacogenomic information about metabolizing enzymes/transporters in labelling to provide clinicians with the information they need to adjust the dose appropriately[27]. Such information also may suggest considering alternative drugs, if the patient is already under medication and there is an expectation of risks from drug-drug interactions. For the pregnancy population, it is still unclear how maternal/placenta phenotypes can affect the safety and efficacy profile of the drug to the mother herself and to the fetus in the presence of myriad physiological adaptations. Currently, determination of fetal pharmacogenomic information is not part of pharmacotherapeutics and unlikely to be significant as the expression of fetal enzymes and transporters are very low, if not absent. Clinical applications of prenatal pharmacogenomics could include both prospective testing to identify pregnancies likely to have significantly altered placental transfer, allowing for changes in dosing and medication selection to optimize safety and efficacy, as well as retrospective testing to identify whether the fetus has been previously 
exposed to significant risk [28]. Understanding the impact of maternal genotypes on the drug exposure can help to describe part of interindividual variability in drug kinetics, contribute to better understanding the impact of physiology, and further guide if dose adjustment is required [29,30,22]. The interplay effect of pregnancy and CYP2D6 phenotypes may have clinical implications for CYP2D6 drug substrates with a narrow therapeutic range or low therapeutic index. Because the effect may vary from drug to drug, any such treatment warrants a reevaluation of the dose when a woman becomes pregnant.

\section{Current status of pregnancy PBPK applications}

Modelling and simulation tools, so far, have been applied to predict "gestational pharmacokinetics" with the aim to determine safe and efficacious doses more efficiently. Population pharmacokinetics plays an important role in this area due to the nature of the limited number of samples that can be collected from each pregnant patient and also to the strength of this approach in borrowing information from different patients to derive a conclusion from sparse data [31-35]. While population pharmacokinetic approaches can be applied to understand the changes in PK during pregnancy if observed concentration data exist, its application to investigate new drugs and dosing proposals is challenging. In addition, mapping and extrapolating the obtained results beyond the data used to derive the model to understand the highly dynamic physiological status during pregnancy is questionable.

The PBPK approach is another tool that enables prediction of drug exposure in pregnant women based on preclinical data on drug kinetics and physicochemical properties and inclusion of gestational age-related changes in physiological parameters. The major benefit of pregnancy PBPK models is the incorporation of gestational agedependent changes in patient physiology (e.g., cardiac output and feto-placental unit) and the activities of metabolizing enzyme and drug transporters in combination with the possibility to disentangle aspects of intersubject variability that stems from phenotypes or biometric differences (Figure 2). Furthermore, these approaches offer the possibility to comprehend non-linearity in drug pharmacokinetics, in addition to enabling extrapolation to different populations or assessing drug interactions.

Building a pregnancy PBPK model should be seen as "add-ins" on top of the normal PBPK for non-pregnant women, through incorporating physiological changes during pregnancy as continuous functions linked to the baseline values of the physiological parameters, such as bodyweight, cardiac output and metabolic changes. The required parameters for building PBPK model is highly depend on the granularity of the model and/or on the aim of the model. A detailed PBPK model needs more parameters than a simple PBPK model depending on the mechanism of the physiological features to be captured in the model.

For example if the pregnancy PBPK model is evaluating the maternal plasma pharmacokinetics for renally eliminated drugs via glomerular filtration, then gestational-dependent changes in renal functions are of major interest. If the aim of the model is to investigate the maternal plasma pharmacokinetics of renally drugs eliminated via filtration and active processes, then the model should include parameters that describe the changes in transporter kinetics in addition to changes to the passive processes that my occurs during pregnancy. The model can be complex if the aim is to investigate kinetics of drugs that also undergo metabolism where there are temporal changes to the activity of the involved metabolizing enzymes. The pregnancy PBPK model can be more complex 
if the aim is to investigate the transplacental passage of drugs known to be affected by placental transports or metabolizing enzymes and in PBPK terms this model requires permeability-limited models where (saturated or unsaturated) kinetics can be evaluated [36]. The complexity of the model can be further increased if the model is developed to assess the fetal systemic or organ exposure, where detailed physiological parameters are required for describing the growth of fetal organs, their blood perfusions and compositions [37-39]. Differences in the structure of the basline (non-pregnant) and dynamic (pregnant) PBPK models have been reviewed [40,41]. Furthermore, within a PBPK model, different predictive tools, which further challenge the possibility of mapping the model parameters.

Due to the physiological complexity, pregnancy PBPK models by nature should retain a level of complexity to reflect the dynamic status but without losing their potential capabilities. This complexity in pregnancy PBPK model is often associated with uncertainty in the model parameters. Preclinical and nonclinical data can contribute to better understanding of the system and reduce the model uncertainty. For example, experimental data from human placental perfusion experiment can be used to parametrize the placental diffusion parameters within the PBPK model [42]. An alternative way to parametrize the trasplacental permeability is the use of cell lines permeability data [36]. Quantification of gestational-dependent placental transporters expression and in vitro experiment of cell lines allows expansion of the model to further facilitate the investigation of transporter kinetics at different gestational age. while, in vitro kinetics of transporters and metabolizing enzymes can be used as assumed as same in nonpregnant women, the in vivo metabolism can be different in pregnant women due to the perturbation in the media such as the reduction in binding protein levels and other factors known to affect protein kinetics such as the elevation of plasma free fatty acids. In vitro measurement of unbound drug in maternal plasma as well as in umbilical cord plasma is important PBPK parameter not only for drug kinetics, but also in order to assess drug safety to the mother and her fetus

So far, the pregnancy PBPK model has been primarily applied to predict any alteration in drug kinetics during pregnancy after being validated for adequate prediction in non-pregnant subjects (see examples in Table I). The increasing applications of pregnancy-PBPK models has aided in building confidence around this approach. These applications can guide dosage adjustment to achieve a target therapeutic window (concentration or exposure), usually adopted from non-pregnant women (or men) and assuming the exposure-response relationship is valid. While this can be a safe assumption for some drugs with wide therapeutic windows, it can be hazardous for antiarrhythmics and the majority of CNS acting drugs [43]. Pregnancy may alter drugs response due to specific receptor alterations from the nonpregnant state (Smiley 1996) or increase drug sensitivity which may lead to increase adverse effects over non-pregnant individuals or to the fetus [44,45]. Even at doses that have been shown to be safe for the mother, prolonged use of benzodiazepines, specially, near term is contraindicated because of neonatal toxicity and withdrawal symptoms.

\section{Examples of pregnancy PBPK model applications}

\section{Quetiapine}


Quetiapine is an atypical antipsychotic drug used for management of bipolar disorder in adults and during pregnancy [46,47]. Quetiapine is mainly metabolized by cytochrome P450 enzyme CYP3A4 (approximately 80\%) with minor contributions attributable to CYP2D6 [48]. Both enzymes are induced during pregnancy [24]. The increase in drug clearance during pregnancy reflected the observed lower plasma concentrations of quetiapine compared to postpartum level and that pregnant patients may need higher doses to maintain consistent plasma concentrations and efficacy. A pregnancy PBPK approach has been applied to optimise the required dose throughout gestation by targeting a therapeutic range of $50-500 \mathrm{ng} / \mathrm{ml}$ [49]. The model was validated using nonpregnant population data and then checked for it is performance in during pregnancy using therapeutic drug monitoring data. The pregnancy PBPK predicted decrease in trough concentration during pregnancy compared with non-pregnant subjects and proposed higher dosing 500-700 mg twice daily to achieve the target therapeutic window.

\section{Chloroquine}

Chloroquine has been used for the treatment of malaria and for prophylactic treatment during pregnancy when in the judgment of the physician the benefit outweighs the potential risk to the fetus. The Zika virus infection during pregnancy can lead to reduced fetal brain tissue, ocular damage, congenital contractures, restriction in body movement and other birth defects of the new born infant to infected mother [50]. In vitro studies have highlighted that chloroquine is capable of inhibiting Zika virus endocytosis in brain cells [51,52] and in mice [53,51]. The drug has not been approved for this indication.

Pregnancy PBPK approaches have been applied to develop a predictive model for chloroquine exposure to identify an optimal maternal/fetal dosing regimen to prevent Zika virus endocytosis in brain cells by targeting a therapeutic chloroquine plasma window of 0.3-2 $\mu \mathrm{M}$ [54]. The PBPK model was first validated using 13 non-pregnancy and 3 pregnancy clinical studies to ensure that the model captured chloroquine pharmacokinetics during pregnancy. The pregnancy PBPK model was then run for current chloroquine dosing regimens used in rheumatoid arthritis, systemic lupus erythematosus, and malaria to assess their ability to target the therapeutic window. These dosing regimens identified that weekly doses used in malaria were not sufficient to reach the lower therapeutic window, while daily doses of $150 \mathrm{mg}$ of chloroquine enabled targeting to within therapeutic window. This was partly a result of the longitudinal physiological changes during gestation highlighted in Figure 3, in addition to alterations in the contribution of each CYP isozyme metabolic pathway (fraction metabolism by each CYP isozyme: fmCYP) towards chloroquine metabolism. This was exhibited as a reduction in the fmCYP for $3 \mathrm{~A} 4$ and $2 \mathrm{C} 8$ and increase in 2D6. The final dosing regimen proposed loading doses of $600 \mathrm{mg}$ on day $1,300 \mathrm{mg}$ on day 2 and 3, and 150 $\mathrm{mg}$ thereafter and illustrates a framework where pregnancy PBPK modelling can be used to support repurposing of medicines in pregnancy.

\section{Piperaquine}

Piperaquine is an antimalarial drug that has gained interest for use during pregnancy in response to increasing resistance towards sulfadoxine-pyrimethamine. The availability of in-vitro metabolic clearance data is limited for piperaquine with CYP3A4 identified as the major metabolic pathway and CYP2B6 playing a minor role [55]. In many developing countries, co-infection with HIV is common during pregnancy making pregnant women more 
vulnerable to the complication of malaria, such as anaemia, placental parasitemia and low birthweight [56]. The fact that these women need HIV treatment, usually combined therapy, the potential of interaction between HIV drugs, anti-malarial drugs and the physiological changes due to the gestation that can affect the drugs kinetics, can result in highly complex clinical situation. Yet, little is known about the impact of HIV mediated drug-drug interactions on piperaquine PKs during pregnancy and whether prior knowledge can be extrapolated from an ethnic population to others. The pregnancy PBPK approach has been used to predict PKs in non-pregnant and pregnant patients, which was validated in distinct customised population groups from Thailand, Sudan and Papua New Guinea [57]. First the piperaquine PBPK model was built and verified in Caucasian non-pregnant healthy subjects. The piperaquine PBPK model was then parameterised using physiological parameters from the three target populations and verified for capturing the drug kinetics in non-pregnant women.

The ethnic-dependent piperaquine PBPK model was then applied to predict the drug kinetics during pregnancy in the target populations assuming the trajectories for pregnancy parameters for these three populations are similar to those in Caucasian pregnant women and baseline is only ethnic-dependent, where data available. The pregnancy PBPK model for these populations was used to assess the impact of efavirenz (CYP3A4 induction) or ritonavir (CYP3A4 inhibition) on piperaquine concentration. Their results indicated no significant differences piperaquine concentrations during pregnancy with a predicted $\mathrm{AUC}_{\text {ratio }}$ in the range 0.56-0.8 and 1.64-1.79 for efavirenz and ritonavir, respectively, over GW 10-40 gestational weeks. No dosing adjustment was suggested for piperaquine in these drug-drug interaction scenarios [57], probably due to the fact that the effect of the inducer on CYP3A4 is partially counteracted by the effect of the inhibitor. It is also worth mentioning that while antiretroviral-mediated drug-drug interaction (DDIs) could significantly alter piperaquine PKs due to other reasons, the framework followed in this assessment indicate the promising field of pregnancy PBPK model applications.

\section{Paroxetine: genotype-based dosing}

Paroxetine is a selective serotonin reuptake inhibitors (SSRIs) and is used to treat conditions such as major depressive disorder, social anxiety disorder, anxiety disorder and obsessive-compulsive disorder [58,59]. Its primary metabolism route is trough CYP2D6 with smaller contributions from CYPs 3A4, 1A2, C219 and 3A5 [60]. In addition, paroxetine is known to be a mechanism-based inhibitor of CYP2D6 [61-63]. Aside from the aforementioned physiological changes associated with gestation which impacts upon drug pharmacokinetics, a consequence of the longitudinal increase in the activity of CYP2D6 during gestation results in a $50 \%$ decrease in paroxetine plasma levels [59,64-67,21]. This is further confounded by the polymorphic nature of CYP2D6, which results in an approximate 7-fold difference in paroxetine clearance between the extensive metabolism (EM) and poor metaboliser (PM) phenotypes [68,63]. Given the risks of poor control of mental health to both mother and fetus, coupled with post-natal risks of neonatal withdrawal syndrome and particularly persistent pulmonary hypertension of the new-born (PPHN) [69] [70].

The pregnancy PBPK modelling approach was used to provide a clinically relevant dose titration strategies [71] when considering the CYP2D6 phenotype status patients by targeting a paroxetine plasma window of 20-60 $\mathrm{ng} / \mathrm{mL}[72,73]$. The PBPK model workflow validated the pregnancy model through: (i) 3 single dose and 2 multiple dosing studies in non-pregnancy subjects; (ii) non-genotyped pregnant subjects throughout gestation and (iii) genotyped (EM, PM and UM) pregnant subjects at the mid-point of each trimester. With knowledge of the plasma therapeutic range, this approach allowed dose optimisation across gestation specifically for EM, PM and 
UM phenotypes targeting this therapeutic range, and culminated in a requirement for daily doses in-excess of the standard $20 \mathrm{mg}$ dose throughout gestation. For each trimester (T), a dose titration was required for EM (T1: 30 mg; T2: $40 \mathrm{mg}$; T3 $40 \mathrm{mg}$ ), PM (T1: $20 \mathrm{mg}$; T2: $30 \mathrm{mg}$; T3 $30 \mathrm{mg}$ ) and for UM (T1: $40 \mathrm{mg}$; T2: $40 \mathrm{mg}$; T3 40 $\mathrm{mg}$ ). Using the pregnancy PBPK modelling approach, this study highlights how precision dosing could be implemented within clinical practice with polymorphic CYP isozymes to support optimisation of drug therapy.

\section{Efavirenz: genotype-based dosing}

The first-line treatment for acquired immune deficiency syndrome (AIDS) often includes non-nucleoside reverse transcriptase inhibitor (NNRTI) and two nucleoside reverse transcriptase inhibitors (NRTI) [74]. Within these treatment approach, the NNRTI efavirenz commonly utilised as a first-line agent in most regimens at a dose of $600 \mathrm{mg}$ daily. Efavirenz is predominantly metabolised by CYP2B6 [75] and is an inducer of CYP3A4 [76,77]. Efavirenz has a linear pharmacokinetics behaviour, and steady-state plasma concentration are reached within 7 days [78]. It is a standard first-line treatment in paediatrics or pregnancy population groups [79] [80]. Several important CYP2B6 SNPs have been identified to have a significant impact on drug metabolism with, in some cases, up to $50 \%$ higher frequencies in some populations $[81,82]$.

CYP2B6 is highly polymorphic with at over 100 identified SNPs [83] [84], with the $* 1 / * 1$ genotype considered as wild-type carrier and the $* 6 / * 6$ genotype (poor metaboliser phenotype) being prominent in about $15-40 \%$ in Asians and more than 50\% in African-Americans population [85-87]. Furthermore, the *6/*6 genotype can often result in a 2-3-fold higher efavirenz plasma concentration [88,89,82,90], and hence an increased ability to induce CYP3A4 [77,91,92].

Given the sparsity of studies considering efavirenz pharmacokinetics in pregnancy and the lack of knowledge on the impact of the poor metaboliser phenotypes during gestation, a pregnancy PBPK modelling approach was utilised [74] aimed at assessing the impact of CYP2B6 phenotypic status efavirenz dosing during the third trimester in order to assess the suitable of a recently recommend lower daily dose (400 mg) [75]. This study demonstrated an approximate 2-fold decrease in poor metaboliser clearance when compared to extensive metabolisers, with 1.4-fold increase in peak plasma concentration [74]. This pregnancy PBPK study demonstrated that approximately $57 \%$ extensive metaboliser patients in trimester 3 possessed trough concentration below the lower therapeutic target of $1 \mathrm{mg} / \mathrm{L}$, suggesting a 400-mg dose may lead to a significant number of extensive metaboliser patients being sub-therapeutic, and highlights the importance of pregnancy PBPK modelling in assessing the complex interplay between longitudinal physiological changes during gestation and the pharmacogenomic risks associated with genotype/phenotype pregnant patient groups.

\section{Fetal Exposure}

The application of PBPK models to describe fetal exposure have been reported for many drugs, including emtricitabine, tenofovir, nevirapine, midazolam, theophylline, darunavir, dolutegravir, zidovudine and acetaminophen (Table 1). In most of these examples, transplacental transfer parameters were estimated from the ex-vivo human placenta perfusion experiments and then were implemented in pregnancy PBPK models that have been developed in both non-pregnant and pregnant women. Model verifications were done by comparing observed 
maternal and cord blood concentrations to predicted concentrations. For examples, the fetal PK profiles for three antiretroviral drugs, emtricitabine, tenofovir and nevirapine were predicted after scaling ex vivo parameters from perfuming a human cotyledon to the whole placenta and then integrating within pregnancy PBPK models developed for these drugs [76,77]. Both emtricitabine and tenofovir are renally cleared compounds, while nevirapine is metabolized by the cytochrome CYP3A4, CYP2B6 and CYP2D6 pathways. was developed to predict maternal and fetal pharmacokinetics (PK). Models prediction for maternal and fetal systemic exposures are given in Figure 4. 


\section{Maternal}
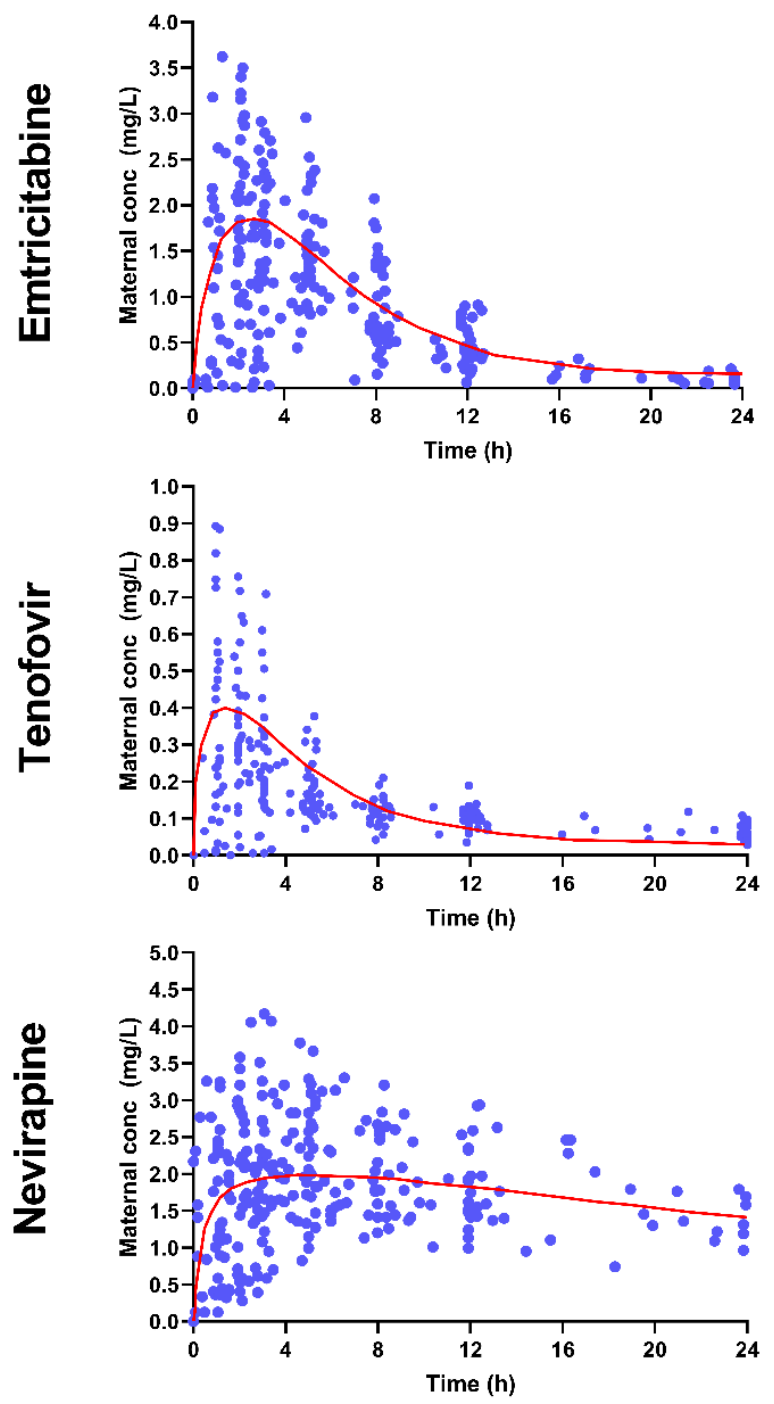

Fetal
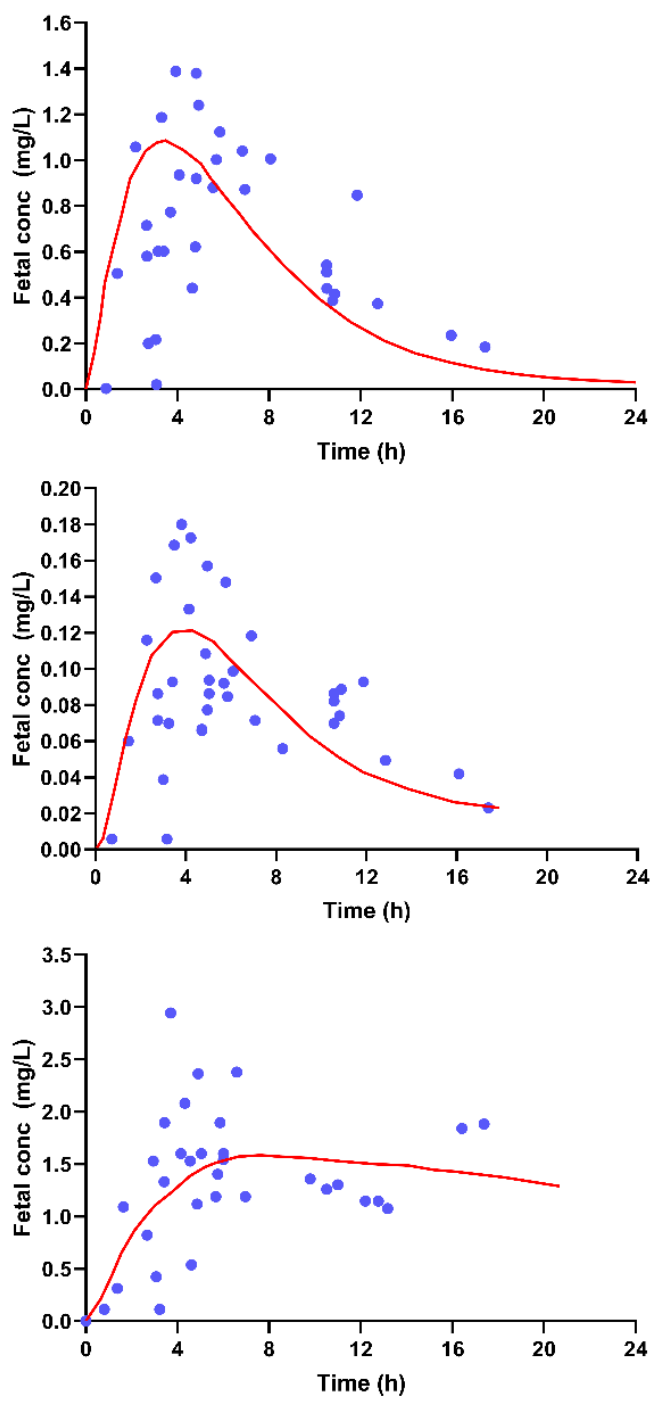

Figure 4: Maternal and fetal concentrations of emtricitabine, tenofovir and nevirapine [76,77]. Squares represent observed data; circles represent fetal (umbilical) data at delivery; Lines represent PBPK predictions for an average subject.

\section{Assessment of maternal dose based on fetal target}

Darunavir administered once daily (QD) or twice daily (BID) to treat and prevent human immunodeficiency virus (HIV) during pregnancy. Darunavir is approximately $94 \%$ protein bound, mainly to a-1-acid glycoprotein. Biotransformation is almost exclusively mediated by CYP3A4. Clinically, darunavir is coadministered with the potent CYP3A4 inhibitor ritonavir,to reduce darunavir clearance and maintain higher plasma concentrations throughout the dosing interval [78]. 
Pregnancy PBPK approaches was applied to develop a predictive model for both maternal and fetal darunavir systemic exposure at term in the presence of the inhibitor [79]. Data from ex vivo human placental perfusion experiment were integrated and used within the pregnancy PBPK model to parameterize the transplacental clearances of darunavir. The developed model was then verified against observed maternal and umbilical cord concentration during delivery. The verified feto-maternal PBPK model was then used to simulate and evaluate fetal darunavir exposure after different maternal darunavir/ritonavir dosing regimens (Figure 5). A therapeutic target trough concentration of $0.55 \mathrm{mg} / \mathrm{L}$ in the umbilical cord was used for darunavir in the presence of ritonavir.

Simulation showed that the standard dosing regimen for darunavir/ritonavir (600/100 $\mathrm{mg}$ twice a day) resulted in fetal population trough concentration that is higher or around the half-maximal effective darunavir concentration for a resistant virus $(0.55 \mathrm{mg} / \mathrm{L})$. While the standard dosing regimen may provide benefits to the prevention of mother-to-child transmission of HIV, possibly even higher dosing regimens are optimal with regard to fetal benefit, especially in the case of high-risk situations, such as maternal HIV breakthrough at term or if infected women have developed (multiple) resistance to protease inhibitors. Moreover, this study indicates that the experimental placental perfusion data can be integrated with pregnancy PBPK model to simulate fetal drug exposure and assess fetal toxicity or enhance the development of more selectively targeted fetal drug treatments.

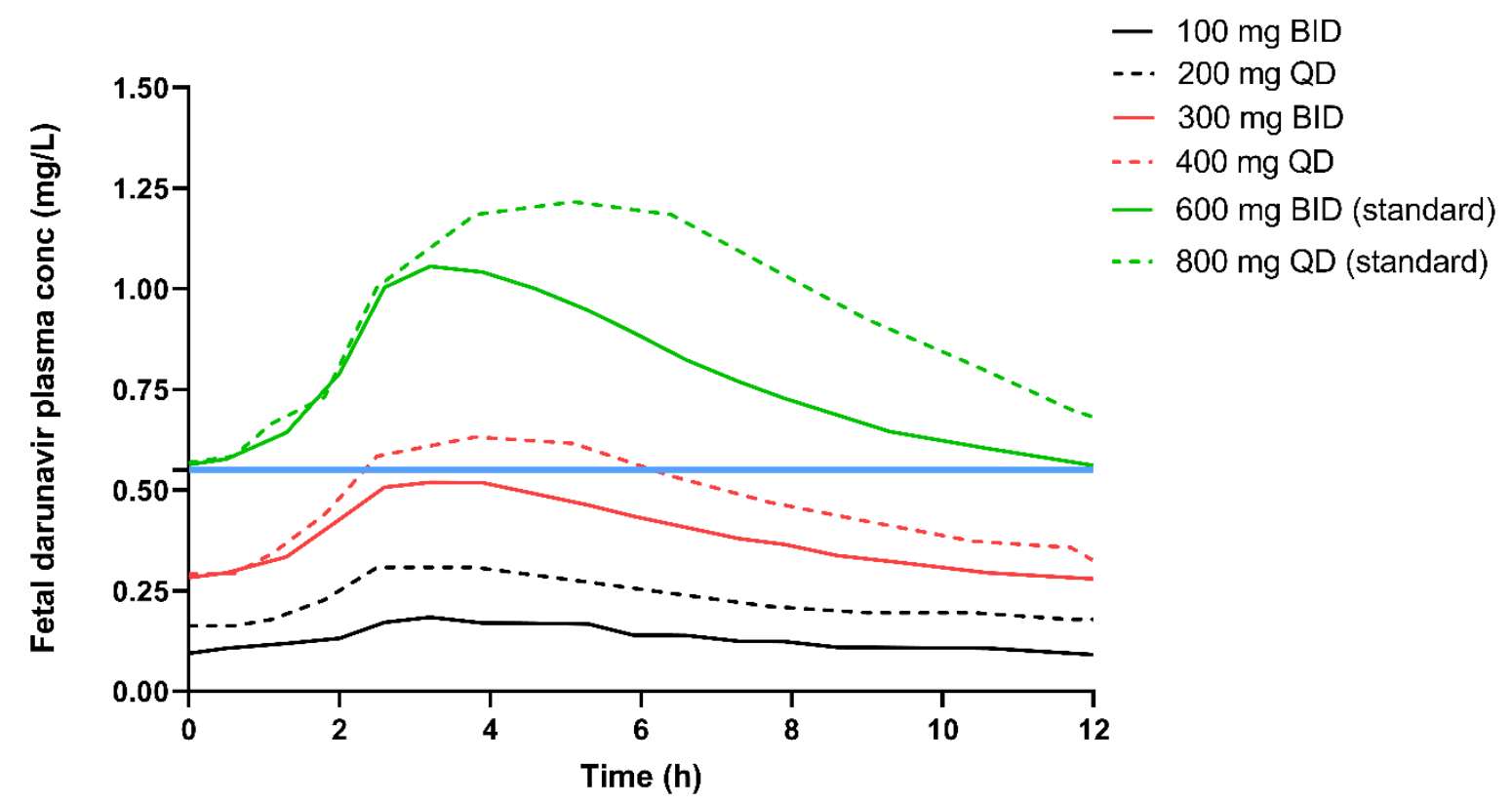

Figure 5. Simulated fetal darunavir concentration-time profiles for several maternal darunavir dosing regimens in the presence of ritonavir, a CYP3A4 inhibitor (Selected profiles around the target trough concentration from [79]. 


\section{Concluding remarks}

The first dose of any drug in pregnant women can be investigated directly by studying the drug kinetics in this population or assessed through PBPK approaches, which have the benefit of accounting for longitudinal changes in the physiological parameters of the model. Dosages of drugs may need to be increased during pregnancy in order to avoid loss of efficacy if the drug is predominantly cleared by renal or/and metabolised by CYP3A4, CYP2D6 and CYP2C9. Other non-CYP450s enzymes reported to induced during pregnancy are uridine diphosphate glucuronosyltransferase (UGT) UGT1A4 and UGT2B7 isoenzymes [8]. It is expected that if the drug elimination is enhanced during pregnancy, then the liability to drug-drug interaction will be lower compared to non-pregnant subjects, which may give an opportunity to pregnant women to benefit from such drugs. On the other hand, dosage of narrow therapeutic window drugs predominantly metabolised by CYP1A2 and CYP2C19 in non-pregnant healthy subjects should be reduced during pregnancy, especially during the third trimester to minimize their potential toxicity. However, these rules might be not straightforward due to the interplay between different factors affecting the clearance, including binding protein, co-medication and co-morbidity. These situations can be assessed by applying a PBPK approach that embraces all these elements and helps to better direct further studies and relax some ethical constrains rising from potential risk of harm to the pregnant women or her fetus(es).

Most current applications of pregnancy PBPK approaches tend to predict plasma concentration-time profiles during pregnancy providing that the non-pregnant prediction is well characterised and the model includes relevant physiological parameters. However, there is lack of robust data around the understanding of physiological changes to phase-II metabolizing enzymes and transporters. There is still a paucity on how and to what magnitude the geno/phenotypes of these proteins can alter the pharmacokinetics during pregnancy. Ideally, establishing dosing regimens for drugs with narrow therapeutic window for pregnant patients according to their phenotypes and at different points during their pregnancy is a forward step toward prenatal precision medicine. Pregnancy PBPK models that have been built and verified with a particular phenotype, can be easily accommodated to predict drug exposure in other phenotypes.

Going forward, it is imperative to assess whether dose adjustment is required during pregnancy, particularly when in vitro to in vivo extrapolation techniques are part of the model approach. The assessment can be more realistic if any prior knowledge on fetal exposure are added into the PBPK model, prior to assessing the dose adjustment or evaluating drug interactions. Given the mechanistic nature of these models, the future for PBPK modelling is promising with many potential opportunities to be explored, particularly with relevant to DDIs.

\section{Acknowledgements}

The authors thank Eleanor Savill and Anna Kenworthy for their assistance with collecting the references and preparing the manuscript, 


\section{Conflict of interest}

The Authors declare no conflicts of interest to disclose.

\section{Funding}

No funding was received for the preparation of this study.

\section{References}

1. McCormack SA, Best BM (2014) Obstetric Pharmacokinetic Dosing Studies are Urgently Needed. Front Pediatr 2:9. doi:10.3389/fped.2014.00009

2. Pinheiro EA, Stika CS (2020) Drugs in pregnancy: Pharmacologic and physiologic changes that affect clinical care. Semin Perinatol:151221. doi:10.1016/j.semperi.2020.151221

3. Daw JR, Hanley GE, Greyson DL, Morgan SG (2011) Prescription drug use during pregnancy in developed countries: a systematic review. Pharmacoepidemiol Drug Saf 20 (9):895-902. doi: $10.1002 /$ pds. 2184

4. Carvalho B, Wong CA (2015) Drug labeling in the practice of obstetric anesthesia. Am J Obstet Gynecol 212 (1):24-27. doi:10.1016/j.ajog.2014.04.040

5. Herring C, McManus A, Weeks A (2010) Off-label prescribing during pregnancy in the UK: an analysis of 18,000 prescriptions in Liverpool Women's Hospital. Int J Pharm Pract 18 (4):226-229. doi:10.1211/ijpp.18.04.0007

6. Laroche ML, Blin A, Coubret A, Grau M, Roux B, Aubard Y (2020) Off-label prescribing during pregnancy in France: the NeHaVi cohort. Int J Clin Pharmacol Ther. doi:10.5414/CP203578

7. Rayburn WF, Turnbull GL (1995) Off-label drug prescribing on a state university obstetric service. J Reprod Med 40 (3):186-188

8. Anderson GD (2005) Pregnancy-induced changes in pharmacokinetics: a mechanistic-based approach. Clin Pharmacokinet 44 (10):989-1008. doi:10.2165/00003088-200544100-00001 
9. Pariente G, Leibson T, Carls A, Adams-Webber T, Ito S, Koren G (2016) Pregnancy-Associated Changes in Pharmacokinetics: A Systematic Review. PLoS Med 13 (11):e1002160.

doi:10.1371/journal.pmed.1002160

10. Abduljalil K, Furness P, Johnson TN, Rostami-Hodjegan A, Soltani H (2012) Anatomical, physiological and metabolic changes with gestational age during normal pregnancy: a database for parameters required in physiologically based pharmacokinetic modelling. Clin Pharmacokinet 51 (6):365-396. doi:10.2165/11597440-000000000-00000

11. Isoherranen N, Thummel KE (2013) Drug metabolism and transport during pregnancy: how does drug disposition change during pregnancy and what are the mechanisms that cause such changes? Drug Metab Dispos 41 (2):256-262. doi:10.1124/dmd.112.050245

12. FDA (2004) Pharmacokinetics in Pregnancy —. Study Design, Data Analysis, and Impact on Dosing and Labeling. Rockville, MD

13. FDA (2018) Pregnant Women: Scientific and Ethical Considerations for Inclusion in Clinical Trials Guidance for Industry. FDA, Silver Spring, MD

14. FDA (2004) Content and Format of Labeling for Human Prescription Drug and Biological Products: Requirements for Pregnancy and Lactation Labeling. Final Rule. FDA, Silver Spring, MD

15. Hebert MF, Easterling TR, Kirby B, Carr DB, Buchanan ML, Rutherford T, Thummel KE, Fishbein DP, Unadkat JD (2008) Effects of pregnancy on CYP3A and P-glycoprotein activities as measured by disposition of midazolam and digoxin: a University of Washington specialized center of research study. Clin Pharmacol Ther 84 (2):248-253. doi:10.1038/clpt.2008.1

16. Salem F, Abduljalil K, Kamiyama Y, Rostami-Hodjegan A (2016) Considering Age Variation When Coining Drugs as High versus Low Hepatic Extraction Ratio. Drug Metab Dispos 44 (7):10991102. doi:10.1124/dmd.115.067595

17. Bastian JR, Chen H, Zhang H, Rothenberger S, Tarter R, English D, Venkataramanan R, Caritis SN (2017) Dose-adjusted plasma concentrations of sublingual buprenorphine are lower during than after pregnancy. Am J Obstet Gynecol 216 (1):64 e61-64 e67. doi:10.1016/j.ajog.2016.09.095

18. Krauer B, Krauer F (1977) Drug kinetics in pregnancy. Clin Pharmacokinet 2 (3):167-181. doi:10.2165/00003088-197702030-00002 
19. Rodgers T, Rowland M (2006) Physiologically based pharmacokinetic modelling 2: predicting the tissue distribution of acids, very weak bases, neutrals and zwitterions. J Pharm Sci 95 (6):1238-1257. doi:10.1002/jps.20502

20. Berezhkovskiy LM (2004) Determination of volume of distribution at steady state with complete consideration of the kinetics of protein and tissue binding in linear pharmacokinetics. J Pharm Sci 93 (2):364-374. doi:10.1002/jps.10539

21. Wadelius M, Darj E, Frenne G, Rane A (1997) Induction of CYP2D6 in pregnancy. Clin Pharmacol Ther 62 (4):400-407. doi:10.1016/S0009-9236(97)90118-1

22. Ververs FF, Voorbij HA, Zwarts P, Belitser SV, Egberts TC, Visser GH, Schobben AF (2009) Effect of cytochrome P450 2D6 genotype on maternal paroxetine plasma concentrations during pregnancy. Clin Pharmacokinet 48 (10):677-683. doi:10.2165/11318050-000000000-00000

23. Ryu RJ, Eyal S, Easterling TR, Caritis SN, Venkataraman R, Hankins G, Rytting E, Thummel K, Kelly EJ, Risler L, Phillips B, Honaker MT, Shen DD, Hebert MF (2016) Pharmacokinetics of metoprolol during pregnancy and lactation. J Clin Pharmacol 56 (5):581-589. doi:10.1002/jcph.631

24. Tracy TS, Venkataramanan R, Glover DD, Caritis SN, National Institute for Child H, Human Development Network of Maternal-Fetal-Medicine U (2005) Temporal changes in drug metabolism (CYP1A2, CYP2D6 and CYP3A Activity) during pregnancy. Am J Obstet Gynecol 192 (2):633-639. doi:10.1016/j.ajog.2004.08.030

25. O'Hare MF, Kinney CD, Murnaghan GA, McDevitt DG (1984) Pharmacokinetics of propranolol during pregnancy. Eur J Clin Pharmacol 27 (5):583-587. doi:10.1007/bf00556896

26. Carter BL, Driscoll CE, Smith GD (1986) Theophylline clearance during pregnancy. Obstet Gynecol 68 (4):555-559

27. Drozda K, Pacanowski MA, Grimstein C, Zineh I (2018) Pharmacogenetic Labeling of FDAApproved Drugs: A Regulatory Retrospective. JACC Basic Transl Sci 3 (4):545-549. doi:10.1016/j.jacbts.2018.06.001

28. Dorfman EH, Cheng EY, Hebert MF, Thummel KE, Burke W (2016) Prenatal pharmacogenomics: a promising area for research. Pharmacogenomics J 16 (4):303-304. doi:10.1038/tpj.2016.33

29. Haas DM, Quinney SK, Clay JM, Renbarger JL, Hebert MF, Clark S, Umans JG, Caritis SN, Obstetric-Fetal Pharmacology Research Units N (2013) Nifedipine pharmacokinetics are influenced 
by CYP3A5 genotype when used as a preterm labor tocolytic. Am J Perinatol 30 (4):275-281. doi:10.1055/s-0032-1323590

30. Olagunju A, Bolaji O, Neary M, Back D, Khoo S, Owen A (2016) Pregnancy affects nevirapine pharmacokinetics: evidence from a CYP2B6 genotype-guided observational study. Pharmacogenet Genomics 26 (8):381-389. doi:10.1097/FPC.0000000000000227

31. Benaboud S, Ekouevi DK, Urien S, Rey E, Arrive E, Blanche S, Gray G, Sim KL, Avit D, McIntyre J, Nerrienet E, Dabis F, Treluyer JM, Hirt D, Group TEAS (2011) Population pharmacokinetics of nevirapine in HIV-1-infected pregnant women and their neonates. Antimicrob Agents Chemother 55 (1):331-337. doi:10.1128/AAC.00631-10

32. Charles B, Norris R, Xiao X, Hague W (2006) Population pharmacokinetics of metformin in late pregnancy. Ther Drug Monit 28 (1):67-72. doi:10.1097/01.ftd.0000184161.52573.0e

33. Fauchet F, Treluyer JM, Illamola SM, Pressiat C, Lui G, Valade E, Mandelbrot L, Lechedanec J, Delmas S, Blanche S, Warszawski J, Urien S, Tubiana R, Hirt D (2015) Population approach to analyze the pharmacokinetics of free and total lopinavir in HIV-infected pregnant women and consequences for dose adjustment. Antimicrob Agents Chemother 59 (9):5727-5735. doi:10.1128/AAC.00863-15

34. Hoglund RM, Adam I, Hanpithakpong W, Ashton M, Lindegardh N, Day NP, White NJ, Nosten F, Tarning J (2012) A population pharmacokinetic model of piperaquine in pregnant and nonpregnant women with uncomplicated Plasmodium falciparum malaria in Sudan. Malar J 11:398. doi:10.1186/1475-2875-11-398

35. Pillai VC, Han K, Beigi RH, Hankins GD, Clark S, Hebert MF, Easterling TR, Zajicek A, Ren Z, Caritis SN, Venkataramanan R (2015) Population pharmacokinetics of oseltamivir in non-pregnant and pregnant women. Br J Clin Pharmacol 80 (5):1042-1050. doi:10.1111/bcp.12691

36. Zhang Z, Unadkat JD (2017) Development of a Novel Maternal-Fetal Physiologically Based Pharmacokinetic Model II: Verification of the model for passive placental permeability drugs. Drug Metab Dispos 45 (8):939-946. doi:10.1124/dmd.116.073957

37. Abduljalil K, Jamei M, Johnson TN (2019) Fetal Physiologically Based Pharmacokinetic Models: Systems Information on Fetal Blood Components and Binding Proteins. Clin Pharmacokinet. doi:10.1007/s40262-019-00836-3 
38. Abduljalil K, Jamei M, Johnson TN (2019) Fetal Physiologically Based Pharmacokinetic Models: Systems Information on the Growth and Composition of Fetal Organs. Clin Pharmacokinet 58 (2):235-262. doi:10.1007/s40262-018-0685-y

39. Abduljalil K, Johnson TN, Rostami-Hodjegan A (2018) Fetal Physiologically-Based Pharmacokinetic Models: Systems Information on Fetal Biometry and Gross Composition. Clin Pharmacokinet 57 (9):1149-1171. doi:10.1007/s40262-017-0618-1

40. Lu G, Abduljalil K, Jamei M, Johnson TN, Soltani H, Rostami-Hodjegan A (2012) Physiologically-based pharmacokinetic (PBPK) models for assessing the kinetics of xenobiotics during pregnancy: achievements and shortcomings. Curr Drug Metab 13 (6):695-720. doi: $10.2174 / 138920012800840374$

41. Dallmann A, Pfister M, van den Anker J, Eissing T (2018) Physiologically Based Pharmacokinetic Modeling in Pregnancy: A Systematic Review of Published Models. Clin Pharmacol Ther 104 (6):1110-1124. doi:10.1002/cpt.1084

42. Bouazza N, Foissac F, Hirt D, Urien S, Benaboud S, Lui G, Treluyer JM (2019) Methodological Approaches to Evaluate Fetal Drug Exposure. Curr Pharm Des 25 (5):496-504. doi:10.2174/1381612825666190319102812

43. Kallen B, Borg N, Reis M (2013) The use of central nervous system active drugs during pregnancy. Pharmaceuticals (Basel) 6 (10):1221-1286. doi:10.3390/ph6101221

44. Holmes LB, Harvey EA, Coull BA, Huntington KB, Khoshbin S, Hayes AM, Ryan LM (2001) The teratogenicity of anticonvulsant drugs. N Engl J Med 344 (15):1132-1138. doi:10.1056/NEJM200104123441504

45. Banhidy F, Lowry RB, Czeizel AE (2005) Risk and benefit of drug use during pregnancy. Int J Med Sci 2 (3):100-106. doi:10.7150/ijms.2.100

46. Hanley GE, Mintzes B (2014) Patterns of psychotropic medicine use in pregnancy in the United States from 2006 to 2011 among women with private insurance. BMC Pregnancy Childbirth 14:242. doi:10.1186/1471-2393-14-242

47. Ennis ZN, Damkier P (2015) Pregnancy exposure to olanzapine, quetiapine, risperidone, aripiprazole and risk of congenital malformations. A systematic review. Basic Clin Pharmacol Toxicol 116 (4):315-320. doi:10.1111/bcpt.12372 
48. Hasselstrom J, Linnet K (2006) In vitro studies on quetiapine metabolism using the substrate depletion approach with focus on drug-drug interactions. Drug Metabol Drug Interact 21 (3-4):187211. doi:10.1515/dmdi.2006.21.3-4.187

49. Badhan RKS, Macfarlane H (2020) Quetiapine dose optimisation during gestation: a pharmacokinetic modelling study. J Pharm Pharmacol. doi:10.1111/jphp.13236

50. Moore CA, Staples JE, Dobyns WB, Pessoa A, Ventura CV, Fonseca EB, Ribeiro EM, Ventura LO, Neto NN, Arena JF, Rasmussen SA (2017) Characterizing the Pattern of Anomalies in Congenital Zika Syndrome for Pediatric Clinicians. JAMA Pediatr 171 (3):288-295. doi:10.1001/jamapediatrics.2016.3982

51. Shiryaev SA, Mesci P, Pinto A, Fernandes I, Sheets N, Shresta S, Farhy C, Huang CT, Strongin AY, Muotri AR, Terskikh AV (2017) Repurposing of the anti-malaria drug chloroquine for Zika Virus treatment and prophylaxis. Sci Rep 7 (1):15771. doi:10.1038/s41598-017-15467-6

52. Delvecchio R, Higa LM, Pezzuto P, Valadao AL, Garcez PP, Monteiro FL, Loiola EC, Dias AA, Silva FJ, Aliota MT, Caine EA, Osorio JE, Bellio M, O'Connor DH, Rehen S, de Aguiar RS, Savarino A, Campanati L, Tanuri A (2016) Chloroquine, an Endocytosis Blocking Agent, Inhibits Zika Virus Infection in Different Cell Models. Viruses 8 (12). doi:10.3390/v8120322

53. Li C, Zhu X, Ji X, Quanquin N, Deng YQ, Tian M, Aliyari R, Zuo X, Yuan L, Afridi SK, Li XF, Jung JU, Nielsen-Saines K, Qin FX, Qin CF, Xu Z, Cheng G (2017) Chloroquine, a FDA-approved Drug, Prevents Zika Virus Infection and its Associated Congenital Microcephaly in Mice. EBioMedicine 24:189-194. doi:10.1016/j.ebiom.2017.09.034

54. Olafuyi O, Badhan RKS (2019) Dose Optimization of Chloroquine by Pharmacokinetic Modeling During Pregnancy for the Treatment of Zika Virus Infection. J Pharm Sci 108 (1):661-673. doi:10.1016/j.xphs.2018.10.056

55. Lee TM, Huang L, Johnson MK, Lizak P, Kroetz D, Aweeka F, Parikh S (2012) In vitro metabolism of piperaquine is primarily mediated by CYP3A4. Xenobiotica 42 (11):1088-1095. doi:10.3109/00498254.2012.693972

56. Hayes DJ, van Buuren S, ter Kuile FO, Stasinopoulos DM, Rigby RA, Terlouw DJ (2015) Developing regional weight-for-age growth references for malaria-endemic countries to optimize agebased dosing of antimalarials. Bull World Health Organ 93 (2):74-83. doi:10.2471/BLT.14.139113

57. Olafuyi O, Coleman M, Badhan RKS (2017) The application of physiologically based pharmacokinetic modelling to assess the impact of antiretroviral-mediated drug-drug interactions on 
piperaquine antimalarial therapy during pregnancy. Biopharm Drug Dispos 38 (8):464-478.

doi:10.1002/bdd.2087

58. Pae CU, Patkar AA (2007) Paroxetine: current status in psychiatry. Expert Rev Neurother 7 (2):107-120. doi:10.1586/14737175.7.2.107

59. Westin AA, Brekke M, Molden E, Skogvoll E, Spigset O (2017) Selective serotonin reuptake inhibitors and venlafaxine in pregnancy: Changes in drug disposition. PLoS One 12 (7):e0181082. doi:10.1371/journal.pone.0181082

60. Jornil J, Jensen KG, Larsen F, Linnet K (2010) Identification of cytochrome P450 isoforms involved in the metabolism of paroxetine and estimation of their importance for human paroxetine metabolism using a population-based simulator. Drug Metab Dispos 38 (3):376-385.

doi:10.1124/dmd.109.030551

61. Bertelsen KM, Venkatakrishnan K, Von Moltke LL, Obach RS, Greenblatt DJ (2003) Apparent mechanism-based inhibition of human CYP2D6 in vitro by paroxetine: comparison with fluoxetine and quinidine. Drug Metab Dispos 31 (3):289-293. doi:10.1124/dmd.31.3.289

62. Zhao SX, Dalvie DK, Kelly JM, Soglia JR, Frederick KS, Smith EB, Obach RS, Kalgutkar AS (2007) NADPH-dependent covalent binding of [3H]paroxetine to human liver microsomes and S-9 fractions: identification of an electrophilic quinone metabolite of paroxetine. Chemical research in toxicology 20 (11):1649-1657. doi:10.1021/tx700132x

63. Sindrup SH, Brosen K, Gram LF, Hallas J, Skjelbo E, Allen A, Allen GD, Cooper SM, Mellows G, Tasker TC, et al. (1992) The relationship between paroxetine and the sparteine oxidation polymorphism. Clin Pharmacol Ther 51 (3):278-287. doi:10.1038/clpt.1992.23

64. Buchanan ML, Easterling TR, Carr DB, Shen DD, Risler LJ, Nelson WL, Mattison DR, Hebert MF (2009) Clonidine pharmacokinetics in pregnancy. Drug Metab Dispos 37 (4):702-705. doi:10.1124/dmd.108.024984

65. Claessens AJ, Risler LJ, Eyal S, Shen DD, Easterling TR, Hebert MF (2010) CYP2D6 mediates 4hydroxylation of clonidine in vitro: implication for pregnancy-induced changes in clonidine clearance. Drug Metab Dispos 38 (9):1393-1396. doi:10.1124/dmd.110.033878

66. Högstedt S, Lindberg B, Peng DR, Regårdh CG, Rane A (1985) Pregnancy-induced increase in metoprolol metabolism. Clin Pharmacol Ther 37 (6):688-692. doi:10.1038/clpt.1985.114 
67. Tracy TS, Venkataramanan R, Glover DD, Caritis SN, Units NIfCHaHDNoM-F-M (2005) Temporal changes in drug metabolism (CYP1A2, CYP2D6 and CYP3A Activity) during pregnancy. Am J Obstet Gynecol 192 (2):633-639. doi:10.1016/j.ajog.2004.08.030

68. Sindrup SH, Brosen K, Gram LF (1992) Pharmacokinetics of the selective serotonin reuptake inhibitor paroxetine: nonlinearity and relation to the sparteine oxidation polymorphism. Clin Pharmacol Ther 51 (3):288-295. doi:10.1038/clpt.1992.24

69. Kieler H, Artama M, Engeland A, Ericsson Ö, Furu K, Gissler M, Nielsen RB, Nørgaard M, Stephansson O, Valdimarsdottir U, Zoega H, Haglund B (2012) Selective serotonin reuptake inhibitors during pregnancy and risk of persistent pulmonary hypertension in the newborn: population based cohort study from the five Nordic countries. BMJ 344:d8012. doi:10.1136/bmj.d8012

70. Huybrechts KF, Bateman BT, Palmsten K, Desai RJ, Patorno E, Gopalakrishnan C, Levin R, Mogun H, Hernandez-Diaz S (2015) Antidepressant use late in pregnancy and risk of persistent pulmonary hypertension of the newborn. Jama 313 (21):2142-2151. doi:10.1001/jama.2015.5605

71. Almurjan A, Macfarlane H, Badhan RKS Precision dosing-based optimisation of paroxetine during pregnancy for poor and ultrarapid CYP2D6 metabolisers: a virtual clinical trial pharmacokinetics study. Journal of Pharmacy and Pharmacology n/a (n/a). doi:10.1111/jphp.13281

72. Tomita T, Yasui-Furukori N, Nakagami T, Tsuchimine S, Ishioka M, Kaneda A, Nakamura K, Kaneko S (2014) Therapeutic reference range for plasma concentrations of paroxetine in patients with major depressive disorders. Therapeutic drug monitoring 36 (4):480-485.

doi:10.1097/ftd.0000000000000036

73. Hiemke C, Bergemann N, Clement HW, Conca A, Deckert J, Domschke K, Eckermann G, Egberts K, Gerlach M, Greiner C, Gründer G, Haen E, Havemann-Reinecke U, Hefner G, Helmer R, Janssen G, Jaquenoud E, Laux G, Messer T, Mössner R, Müller MJ, Paulzen M, Pfuhlmann B, Riederer P, Saria A, Schoppek B, Schoretsanitis G, Schwarz M, Gracia MS, Stegmann B, Steimer W, Stingl JC, Uhr M, Ulrich S, Unterecker S, Waschgler R, Zernig G, Zurek G, Baumann P (2018) Consensus Guidelines for Therapeutic Drug Monitoring in Neuropsychopharmacology: Update 2017. Pharmacopsychiatry 51 (01/02):9-62. doi:10.1055/s-0043-116492

74. Chetty M, Danckwerts MP, Julsing A (2020) Prediction of the exposure to a 400-mg daily dose of efavirenz in pregnancy: is this dose adequate in extensive metabolisers of CYP2B6? European Journal of Clinical Pharmacology. doi:10.1007/s00228-020-02890-4

75. Dickinson L, Amin J, Else L, Boffito M, Egan D, Owen A, Khoo S, Back D, Orrell C, Clarke A, Losso M, Phanuphak P, Carey D, Cooper DA, Emery S, Puls R (2015) Pharmacokinetic and 
Pharmacodynamic Comparison of Once-Daily Efavirenz (400 mg vs. $600 \mathrm{mg}$ ) in Treatment-Naive HIV-Infected Patients: Results of the ENCORE1 Study. Clinical pharmacology and therapeutics 98 (4):406-416. doi:10.1002/cpt.156

76. De Sousa Mendes M, Hirt D, Vinot C, Valade E, Lui G, Pressiat C, Bouazza N, Foissac F, Blanche S, Le MP, Peytavin G, Treluyer JM, Urien S, Benaboud S (2016) Prediction of human fetal pharmacokinetics using ex vivo human placenta perfusion studies and physiologically based models. Br J Clin Pharmacol 81 (4):646-657. doi:10.1111/bcp.12815

77. De Sousa Mendes M, Lui G, Zheng Y, Pressiat C, Hirt D, Valade E, Bouazza N, Foissac F, Blanche S, Treluyer JM, Urien S, Benaboud S (2017) A Physiologically-Based Pharmacokinetic Model to Predict Human Fetal Exposure for a Drug Metabolized by Several CYP450 Pathways. Clin Pharmacokinet 56 (5):537-550. doi:10.1007/s40262-016-0457-5

78. Colbers A, Greupink R, Litjens C, Burger D, Russel FG (2016) Physiologically Based Modelling of Darunavir/Ritonavir Pharmacokinetics During Pregnancy. Clin Pharmacokinet 55 (3):381-396. doi:10.1007/s40262-015-0325-8

79. Schalkwijk S, Buaben AO, Freriksen JJM, Colbers AP, Burger DM, Greupink R, Russel FGM (2018) Prediction of Fetal Darunavir Exposure by Integrating Human Ex-Vivo Placental Transfer and Physiologically Based Pharmacokinetic Modeling. Clin Pharmacokinet 57 (6):705-716. doi:10.1007/s40262-017-0583-8

80. Best BM, Mirochnick M, Capparelli EV, Stek A, Burchett SK, Holland DT, Read JS, Smith E, Hu C, Spector SA, Connor JD, Team PPS (2006) Impact of pregnancy on abacavir pharmacokinetics. AIDS 20 (4):553-560. doi:10.1097/01.aids.0000210609.52836.d1

81. Schalkwijk S, Colbers A, Konopnicki D, Weizsacker K, Molto J, Tenorio CH, Hawkins D, Taylor G, Wood C, van der Ende M, Burger D, network P (2016) The pharmacokinetics of abacavir $600 \mathrm{mg}$ once daily in HIV-1-positive pregnant women. AIDS 30 (8):1239-1244.

doi:10.1097/QAD.0000000000001046

82. Beaulac-Baillargeon L, Rocheleau S (1994) Paracetamol pharmacokinetics during the first trimester of human pregnancy. Eur J Clin Pharmacol 46 (5):451-454. doi:10.1007/bf00191910

83. Miners JO, Robson RA, Birkett DJ (1986) Paracetamol metabolism in pregnancy. Br J Clin Pharmacol 22 (3):359-362. doi:10.1111/j.1365-2125.1986.tb02901.x 
84. Allegaert K, Peeters MY, Beleyn B, Smits A, Kulo A, van Calsteren K, Deprest J, de Hoon J, Knibbe CA (2015) Paracetamol pharmacokinetics and metabolism in young women. BMC

Anesthesiol 15:163. doi:10.1186/s12871-015-0144-3

85. Mian P, van den Anker JN, van Calsteren K, Annaert P, Tibboel D, Pfister M, Allegaert K, Dallmann A (2019) Physiologically Based Pharmacokinetic Modeling to Characterize Acetaminophen Pharmacokinetics and N-Acetyl-p-Benzoquinone Imine (NAPQI) Formation in Non-Pregnant and Pregnant Women. Clin Pharmacokinet. doi:10.1007/s40262-019-00799-5

86. Kimberlin DF, Weller S, Whitley RJ, Andrews WW, Hauth JC, Lakeman F, Miller G (1998) Pharmacokinetics of oral valacyclovir and acyclovir in late pregnancy. Am J Obstet Gynecol 179 (4):846-851. doi:10.1016/s0002-9378(98)70176-0

87. Frenkel LM, Brown ZA, Bryson YJ, Corey L, Unadkat JD, Hensleigh PA, Arvin AM, Prober CG, Connor JD (1991) Pharmacokinetics of acyclovir in the term human pregnancy and neonate. Am J Obstet Gynecol 164 (2):569-576. doi:10.1016/s0002-9378(11)80023-2

88. Liu XI, Momper JD, Rakhmanina N, van den Anker JN, Green DJ, Burckart GJ, Best BM, Mirochnick M, Capparelli EV, Dallmann A (2020) Physiologically Based Pharmacokinetic Models to Predict Maternal Pharmacokinetics and Fetal Exposure to Emtricitabine and Acyclovir. J Clin Pharmacol 60 (2):240-255. doi:10.1002/jcph.1515

89. Andrew MA, Easterling TR, Carr DB, Shen D, Buchanan ML, Rutherford T, Bennett R, Vicini P, Hebert MF (2007) Amoxicillin pharmacokinetics in pregnant women: modeling and simulations of dosage strategies. Clin Pharmacol Ther 81 (4):547-556. doi:10.1038/sj.clpt.6100126

90. Philipson A (1977) Pharmacokinetics of ampicillin during pregnancy. J Infect Dis 136 (3):370376. doi:10.1093/infdis/136.3.370

91. Chamberlain A, White S, Bawdon R, Thomas S, Larsen B (1993) Pharmacokinetics of ampicillin and sulbactam in pregnancy. Am J Obstet Gynecol 168 (2):667-673. doi:10.1016/00029378(93)90515-k

92. Della Torre M, Hibbard JU, Jeong H, Fischer JH (2010) Betamethasone in pregnancy: influence of maternal body weight and multiple gestation on pharmacokinetics. Am J Obstet Gynecol 203 (3):254 e251-212. doi:10.1016/j.ajog.2010.06.029

93. Petersen MC, Collier CB, Ashley JJ, McBride WG, Nation RL (1983) Disposition of betamethasone in parturient women after intravenous administration. Eur J Clin Pharmacol 25 (6):803-810. doi:10.1007/bf00542524 
94. Ke AB, Milad MA (2019) Evaluation of Maternal Drug Exposure Following the Administration of Antenatal Corticosteroids During Late Pregnancy Using Physiologically-Based Pharmacokinetic Modeling. Clin Pharmacol Ther 106 (1):164-173. doi:10.1002/cpt.1438

95. Zhang H, Bastian Pharm DJ, Zhao W, Chen H, Caritis SN, Shaik I, Chaphekar N, Venkataramanan R (2020) Pregnancy Alters CYP and UGT Mediated Metabolism of Buprenorphine. Ther Drug Monit. doi:10.1097/FTD.0000000000000724

96. Zhang H, Kalluri HV, Bastian JR, Chen H, Alshabi A, Caritis SN, Venkataramanan R (2018) Gestational changes in buprenorphine exposure: A physiologically-based pharmacokinetic analysis. Br J Clin Pharmacol 84 (9):2075-2087. doi:10.1111/bcp.13642

97. Knutti R, Rothweiler H, Schlatter C (1982) The effect of pregnancy on the pharmacokinetics of caffeine. Arch Toxicol Suppl 5:187-192. doi:10.1007/978-3-642-68511-8_33

98. Brazier JL, Ritter J, Berland M, Khenfer D, Faucon G (1983) Pharmacokinetics of caffeine during and after pregnancy. Dev Pharmacol Ther 6 (5):315-322. doi:10.1159/000457332

99. Gaohua L, Abduljalil K, Jamei M, Johnson TN, Rostami-Hodjegan A (2012) A pregnancy physiologically based pharmacokinetic (p-PBPK) model for disposition of drugs metabolized by CYP1A2, CYP2D6 and CYP3A4. Br J Clin Pharmacol 74 (5):873-885. doi:10.1111/j.13652125.2012.04363.X

100. Darakjian LI, Kaddoumi A (2019) Physiologically Based Pharmacokinetic/Pharmacodynamic Model for Caffeine Disposition in Pregnancy. Mol Pharm 16 (3):1340-1349. doi:10.1021/acs.molpharmaceut.8b01276

101. Dallmann A, Ince I, Coboeken K, Eissing T, Hempel G (2018) A Physiologically Based Pharmacokinetic Model for Pregnant Women to Predict the Pharmacokinetics of Drugs Metabolized Via Several Enzymatic Pathways. Clin Pharmacokinet 57 (6):749-768. doi:10.1007/s40262-017-05945

102. Ke AB, Nallani SC, Zhao P, Rostami-Hodjegan A, Isoherranen N, Unadkat JD (2013) A physiologically based pharmacokinetic model to predict disposition of CYP2D6 and CYP1A2 metabolized drugs in pregnant women. Drug Metab Dispos 41 (4):801-813. doi:10.1124/dmd.112.050161

103. Philipson A, Stiernstedt G, Ehrnebo M (1987) Comparison of the pharmacokinetics of cephradine and cefazolin in pregnant and non-pregnant women. Clin Pharmacokinet 12 (2):136-144. doi:10.2165/00003088-198712020-00004 
104. van Hasselt JG, Allegaert K, van Calsteren K, Beijnen JH, Schellens JH, Huitema AD (2014) Semiphysiological versus empirical modelling of the population pharmacokinetics of free and total cefazolin during pregnancy. Biomed Res Int 2014:897216. doi:10.1155/2014/897216

105. Dallmann A, Ince I, Solodenko J, Meyer M, Willmann S, Eissing T, Hempel G (2017) Physiologically Based Pharmacokinetic Modeling of Renally Cleared Drugs in Pregnant Women. Clin Pharmacokinet 56 (12):1525-1541. doi:10.1007/s40262-017-0538-0

106. Karunajeewa HA, Salman S, Mueller I, Baiwog F, Gomorrai S, Law I, Page-Sharp M, Rogerson S, Siba P, Ilett KF, Davis TM (2010) Pharmacokinetics of chloroquine and monodesethylchloroquine in pregnancy. Antimicrob Agents Chemother 54 (3):1186-1192. doi:10.1128/AAC.01269-09

107. Massele AY, Kilewo C, Aden Abdi Y, Tomson G, Diwan VK, Ericsson O, Rimoy G, Gustafsson LL (1997) Chloroquine blood concentrations and malaria prophylaxis in Tanzanian women during the second and third trimesters of pregnancy. Eur J Clin Pharmacol 52 (4):299-305.

doi: $10.1007 / \mathrm{s} 002280050294$

108. Chukwuani MC, Bolaji OO, Onyeji CO, Makinde ON, Ogunbona FA (2004) Evidence for increased metabolism of chloroquine during the early third trimester of human pregnancy. Trop Med Int Health 9 (5):601-605. doi:10.1111/j.1365-3156.2004.01227.x

109. Kozlowska-Boszko B, Gaciong Z, Serafinowicz A, Majchrzak J, Durlik M, Rowinski W, Lao M (1998) Cyclosporine A blood concentration during pregnancy in renal allograft recipients. Transpl Int 11 Suppl 1:S90-93. doi:10.1007/s001470050434

110. Eke AC, Stek AM, Wang J, Kreitchmann R, Shapiro DE, Smith E, Chakhtoura N, Capparelli EV, Mirochnick M, Best BM, Team IPP (2020) Darunavir pharmacokinetics with an increased dose during pregnancy. J Acquir Immune Defic Syndr. doi:10.1097/QAI.0000000000002261

111. Schalkwijk S, Ter Heine R, Colbers A, Capparelli E, Best BM, Cressey TR, Greupink R, Russel FGM, Molto J, Mirochnick M, Karlsson MO, Burger DM (2019) Evaluating darunavir/ritonavir dosing regimens for HIV-positive pregnant women using semi-mechanistic pharmacokinetic modelling. J Antimicrob Chemother 74 (5):1348-1356. doi:10.1093/jac/dky567

112. Jorgensen NP, Thurmann-Nielsen E, Walstad RA (1988) Pharmacokinetics and distribution of diazepam and oxazepam in early pregnancy. Acta Obstet Gynecol Scand 67 (6):493-497. doi: $10.3109 / 00016348809029859$

113. Moore RG, McBride WG (1978) The disposition kinetics of diazepam in pregnant women at parturition. Eur J Clin Pharmacol 13 (4):275-284. doi:10.1007/bf00716363 
114. Kanto JH (1982) Use of benzodiazepines during pregnancy, labour and lactation, with particular reference to pharmacokinetic considerations. Drugs 23 (5):354-380. doi:10.2165/00003495198223050-00002

115. Martin-Suarez A, Sanchez-Hernandez JG, Medina-Barajas F, Perez-Blanco JS, Lanao JM, Garcia-Cuenllas Alvarez L, Calvo MV (2017) Pharmacokinetics and dosing requirements of digoxin in pregnant women treated for fetal supraventricular tachycardia. Expert Rev Clin Pharmacol 10 (8):911-917. doi:10.1080/17512433.2017.1344096

116. Xia B, Heimbach T, Gollen R, Nanavati C, He H (2013) A simplified PBPK modeling approach for prediction of pharmacokinetics of four primarily renally excreted and CYP3A metabolized compounds during pregnancy. AAPS J 15 (4):1012-1024. doi:10.1208/s12248-013-9505-3

117. Mulligan N, Best BM, Wang J, Capparelli EV, Stek A, Barr E, Buschur SL, Acosta EP, Smith E, Chakhtoura N, Burchett S, Mirochnick M, Team IPP (2018) Dolutegravir pharmacokinetics in pregnant and postpartum women living with HIV. AIDS 32 (6):729-737. doi:10.1097/QAD.0000000000001755

118. Waitt C, Orrell C, Walimbwa S, Singh Y, Kintu K, Simmons B, Kaboggoza J, Sihlangu M, Coombs JA, Malaba T, Byamugisha J, Amara A, Gini J, Else L, Heiburg C, Hodel EM, Reynolds H, Mehta U, Byakika-Kibwika P, Hill A, Myer L, Lamorde M, Khoo S (2019) Safety and pharmacokinetics of dolutegravir in pregnant mothers with HIV infection and their neonates: A randomised trial (DolPHIN-1 study). PLoS Med 16 (9):e1002895. doi:10.1371/journal.pmed.1002895

119. Freriksen JJM, Schalkwijk S, Colbers AP, Abduljalil K, Russel FGM, Burger DM, Greupink R (2019) Assessment of Maternal and Fetal Dolutegravir Exposure by Integrating Ex Vivo Placental Perfusion Data and Physiologically-Based Pharmacokinetic Modeling. Clin Pharmacol Ther. doi:10.1002/cpt.1748

120. Kreitchmann R, Schalkwijk S, Best B, Wang J, Colbers A, Stek A, Shapiro D, Cressey T, Mirochnick M, Burger D (2019) Efavirenz pharmacokinetics during pregnancy and infant washout. Antivir Ther 24 (2):95-103. doi:10.3851/IMP3283

121. Lamorde M, Wang X, Neary M, Bisdomini E, Nakalema S, Byakika-Kibwika P, Mukonzo JK, Khan W, Owen A, McClure M, Boffito M (2018) Pharmacokinetics, Pharmacodynamics, and Pharmacogenetics of Efavirenz 400 mg Once Daily During Pregnancy and Post-Partum. Clin Infect Dis 67 (5):785-790. doi:10.1093/cid/ciy161

122. Cressey TR, Stek A, Capparelli E, Bowonwatanuwong C, Prommas S, Sirivatanapa P, Yuthavisuthi P, Neungton C, Huo Y, Smith E, Best BM, Mirochnick M, Team IP (2012) Efavirenz 
pharmacokinetics during the third trimester of pregnancy and postpartum. J Acquir Immune Defic Syndr 59 (3):245-252. doi:10.1097/QAI.0b013e31823ff052

123. Atoyebi SA, Rajoli RKR, Adejuyigbe E, Owen A, Bolaji O, Siccardi M, Olagunju A (2019) Using mechanistic physiologically-based pharmacokinetic models to assess prenatal drug exposure: Thalidomide versus efavirenz as case studies. Eur J Pharm Sci 140:105068. doi:10.1016/j.ejps.2019.105068

124. Valade E, Treluyer JM, Dabis F, Arrive E, Pannier E, Benaboud S, Fauchet F, Bouazza N, Foissac F, Urien S, Hirt D (2014) Modified renal function in pregnancy: impact on emtricitabine pharmacokinetics. Br J Clin Pharmacol 78 (6):1378-1386. doi:10.1111/bcp.12457

125. Stek AM, Best BM, Luo W, Capparelli E, Burchett S, Hu C, Li H, Read JS, Jennings A, Barr E, Smith E, Rossi SS, Mirochnick M (2012) Effect of pregnancy on emtricitabine pharmacokinetics. HIV Med 13 (4):226-235. doi:10.1111/j.1468-1293.2011.00965.x

126. De Sousa Mendes M, Hirt D, Urien S, Valade E, Bouazza N, Foissac F, Blanche S, Treluyer JM, Benaboud S (2015) Physiologically-based pharmacokinetic modeling of renally excreted antiretroviral drugs in pregnant women. Br J Clin Pharmacol 80 (5):1031-1041. doi:10.1111/bcp.12685

127. Hebert MF, Ma X, Naraharisetti SB, Krudys KM, Umans JG, Hankins GD, Caritis SN, Miodovnik M, Mattison DR, Unadkat JD, Kelly EJ, Blough D, Cobelli C, Ahmed MS, Snodgrass WR, Carr DB, Easterling TR, Vicini P, Obstetric-Fetal Pharmacology Research Unit N (2009) Are we optimizing gestational diabetes treatment with glyburide? The pharmacologic basis for better clinical practice. Clin Pharmacol Ther 85 (6):607-614. doi:10.1038/clpt.2009.5

128. Ke AB, Nallani SC, Zhao P, Rostami-Hodjegan A, Unadkat JD (2014) Expansion of a PBPK model to predict disposition in pregnant women of drugs cleared via multiple CYP enzymes, including CYP2B6, CYP2C9 and CYP2C19. Br J Clin Pharmacol 77 (3):554-570. doi:10.1111/bcp.12207

129. Heikkila A, Renkonen OV, Erkkola R (1992) Pharmacokinetics and transplacental passage of imipenem during pregnancy. Antimicrob Agents Chemother 36 (12):2652-2655.

doi:10.1128/aac.36.12.2652

130. Cressey TR, Best BM, Achalapong J, Stek A, Wang J, Chotivanich N, Yuthavisuthi P, Suriyachai P, Prommas S, Shapiro DE, Watts DH, Smith E, Capparelli E, Kreitchmann R, Mirochnick M, team IP (2013) Reduced indinavir exposure during pregnancy. Br J Clin Pharmacol 76 (3):475483. doi:10.1111/bcp. 12078 
131. Unadkat JD, Wara DW, Hughes MD, Mathias AA, Holland DT, Paul ME, Connor J, Huang S, Nguyen BY, Watts DH, Mofenson LM, Smith E, Deutsch P, Kaiser KA, Tuomala RE (2007) Pharmacokinetics and safety of indinavir in human immunodeficiency virus-infected pregnant women. Antimicrob Agents Chemother 51 (2):783-786. doi:10.1128/AAC.00420-06

132. Ke AB, Nallani SC, Zhao P, Rostami-Hodjegan A, Unadkat JD (2012) A PBPK Model to Predict Disposition of CYP3A-Metabolized Drugs in Pregnant Women: Verification and Discerning the Site of CYP3A Induction. CPT Pharmacometrics Syst Pharmacol 1:e3. doi:10.1038/psp.2012.2

133. Rytting E, Nanovskaya TN, Wang X, Vernikovskaya DI, Clark SM, Cochran M, Abdel-Rahman SM, Venkataramanan R, Caritis SN, Hankins GD, Ahmed MS (2014) Pharmacokinetics of indomethacin in pregnancy. Clin Pharmacokinet 53 (6):545-551. doi:10.1007/s40262-014-0133-6

134. Alqahtani S, Kaddoumi A (2015) Development of Physiologically Based

Pharmacokinetic/Pharmacodynamic Model for Indomethacin Disposition in Pregnancy. PLoS One 10 (10):e0139762. doi:10.1371/journal.pone.0139762

135. Fischer JH, Sarto GE, Hardman J, Endres L, Jenkins TM, Kilpatrick SJ, Jeong H, Geller S, Deyo K, Fischer PA, Rodvold KA (2014) Influence of gestational age and body weight on the pharmacokinetics of labetalol in pregnancy. Clin Pharmacokinet 53 (4):373-383. doi:10.1007/s40262013-0123-0

136. Benaboud S, Treluyer JM, Urien S, Blanche S, Bouazza N, Chappuy H, Rey E, Pannier E, Firtion G, Launay O, Hirt D (2012) Pregnancy-related effects on lamivudine pharmacokinetics in a population study with 228 women. Antimicrob Agents Chemother 56 (2):776-782.

doi:10.1128/AAC.00370-11

137. Eyal S, Easterling TR, Carr D, Umans JG, Miodovnik M, Hankins GD, Clark SM, Risler L, Wang J, Kelly EJ, Shen DD, Hebert MF (2010) Pharmacokinetics of metformin during pregnancy. Drug Metab Dispos 38 (5):833-840. doi:10.1124/dmd.109.031245

138. Liao MZ, Flood Nichols SK, Ahmed M, Clark S, Hankins GD, Caritis S, Venkataramanan R, Haas D, Quinney SK, Haneline LS, Tita AT, Manuck T, Wang J, Thummel KE, Brown LM, Ren Z, Easterling TR, Hebert MF (2020) Effects of Pregnancy on the Pharmacokinetics of Metformin. Drug Metab Dispos. doi:10.1124/dmd.119.088435

139. Jogiraju VK, Avvari S, Gollen R, Taft DR (2017) Application of physiologically based pharmacokinetic modeling to predict drug disposition in pregnant populations. Biopharm Drug Dispos 38 (7):426-438. doi:10.1002/bdd.2081 
140. Wolff K, Boys A, Rostami-Hodjegan A, Hay A, Raistrick D (2005) Changes to methadone clearance during pregnancy. Eur J Clin Pharmacol 61 (10):763-768. doi:10.1007/s00228-005-0035-5

141. Pond SM, Kreek MJ, Tong TG, Raghunath J, Benowitz NL (1985) Altered methadone pharmacokinetics in methadone-maintained pregnant women. J Pharmacol Exp Ther 233 (1):1-6

142. Jarvis MA, Wu-Pong S, Kniseley JS, Schnoll SH (1999) Alterations in methadone metabolism during late pregnancy. J Addict Dis 18 (4):51-61. doi:10.1300/J069v18n04_05

143. Swift RM, Dudley M, DePetrillo P, Camara P, Griffiths W (1989) Altered methadone pharmacokinetics in pregnancy: implications for dosing. J Subst Abuse 1 (4):453-460

144. Albright B, de la Torre L, Skipper B, Price S, Abbott P, Rayburn W (2011) Changes in methadone maintenance therapy during and after pregnancy. J Subst Abuse Treat 41 (4):347-353. doi:10.1016/j.jsat.2011.05.002

145. Hogstedt S, Lindberg B, Peng DR, Regardh CG, Rane A (1985) Pregnancy-induced increase in metoprolol metabolism. Clin Pharmacol Ther 37 (6):688-692. doi:10.1038/clpt.1985.114

146. Hogstedt S, Lindberg B, Rane A (1983) Increased oral clearance of metoprolol in pregnancy. Eur J Clin Pharmacol 24 (2):217-220. doi:10.1007/bf00613820

147. Hogstedt S, Rane A (1993) Plasma concentration-effect relationship of metoprolol during and after pregnancy. Eur J Clin Pharmacol 44 (3):243-246. doi:10.1007/bf00271365

148. Andrew MA, Hebert MF, Vicini P (2008) Physiologically based pharmacokinetic model of midazolam disposition during pregnancy. Conf Proc IEEE Eng Med Biol Soc 2008:5454-5457. doi:10.1109/IEMBS.2008.4650448

149. Zhang Z, Imperial MZ, Patilea-Vrana GI, Wedagedera J, Gaohua L, Unadkat JD (2017) Development of a Novel Maternal-Fetal Physiologically Based Pharmacokinetic Model I: Insights into Factors that Determine Fetal Drug Exposure through Simulations and Sensitivity Analyses. Drug Metab Dispos 45 (8):920-938. doi:10.1124/dmd.117.075192

150. Gerdin E, Salmonson T, Lindberg B, Rane A (1990) Maternal kinetics of morphine during labour. J Perinat Med 18 (6):479-487. doi:10.1515/jpme.1990.18.6.479

151. Capparelli EV, Aweeka F, Hitti J, Stek A, Hu C, Burchett SK, Best B, Smith E, Read JS, Watts H, Nachman S, Thorpe EM, Jr., Spector SA, Jimenez E, Shearer WT, Foca M, Mirochnick M, Team PSS, Team PPS (2008) Chronic administration of nevirapine during pregnancy: impact of pregnancy on pharmacokinetics. HIV Med 9 (4):214-220. doi:10.1111/j.1468-1293.2008.00553.x 
152. Lamorde M, Byakika-Kibwika P, Okaba-Kayom V, Flaherty JP, Boffito M, Namakula R, Ryan M, Nakabiito C, Back DJ, Khoo S, Merry C, Scarsi KK (2010) Suboptimal nevirapine steady-state pharmacokinetics during intrapartum compared with postpartum in HIV-1-seropositive Ugandan women. J Acquir Immune Defic Syndr 55 (3):345-350. doi:10.1097/QAI.0b013e3181e9871b 153. Prevost RR, Akl SA, Whybrew WD, Sibai BM (1992) Oral nifedipine pharmacokinetics in pregnancy-induced hypertension. Pharmacotherapy 12 (3):174-177

154. Krecic-Shepard ME, Park K, Barnas C, Slimko J, Kerwin DR, Schwartz JB (2000) Race and sex influence clearance of nifedipine: results of a population study. Clin Pharmacol Ther 68 (2):130-142. doi:10.1067/mcp.2000.108678

155. Beigi RH, Han K, Venkataramanan R, Hankins GD, Clark S, Hebert MF, Easterling T, Zajicek A, Ren Z, Mattison DR, Caritis SN, Obstetric-Fetal Pharmacology Research Units N (2011) Pharmacokinetics of oseltamivir among pregnant and nonpregnant women. Am J Obstet Gynecol 204 (6 Suppl 1):S84-88. doi:10.1016/j.ajog.2011.03.002

156. Tomson T, Lindbom U, Ekqvist B, Sundqvist A (1994) Disposition of carbamazepine and phenytoin in pregnancy. Epilepsia 35 (1):131-135. doi:10.1111/j.1528-1157.1994.tb02922.x

157. Yerby MS, Friel PN, McCormick K, Koerner M, Van Allen M, Leavitt AM, Sells CJ, Yerby JA (1990) Pharmacokinetics of anticonvulsants in pregnancy: alterations in plasma protein binding. Epilepsy Res 5 (3):223-228. doi:10.1016/0920-1211(90)90042-t

158. Dickinson RG, Hooper WD, Wood B, Lander CM, Eadie MJ (1989) The effect of pregnancy in humans on the pharmacokinetics of stable isotope labelled phenytoin. Br J Clin Pharmacol 28 (1):1727. doi:10.1111/j.1365-2125.1989.tb03501.x

159. Lander CM, Smith MT, Chalk JB, de Wytt C, Symoniw P, Livingstone I, Eadie MJ (1984) Bioavailability and pharmacokinetics of phenytoin during pregnancy. Eur J Clin Pharmacol 27 (1):105-110

160. Heikkila A, Erkkola R (1991) Pharmacokinetics of piperacillin during pregnancy. J Antimicrob Chemother 28 (3):419-423. doi:10.1093/jac/28.3.419

161. Rijken MJ, McGready R, Phyo AP, Lindegardh N, Tarning J, Laochan N, Than HH, Mu O, Win AK, Singhasivanon P, White N, Nosten F (2011) Pharmacokinetics of dihydroartemisinin and piperaquine in pregnant and nonpregnant women with uncomplicated falciparum malaria. Antimicrob Agents Chemother 55 (12):5500-5506. doi:10.1128/AAC.05067-11 
162. Wangboonskul J, White NJ, Nosten F, ter Kuile F, Moody RR, Taylor RB (1993) Single dose pharmacokinetics of proguanil and its metabolites in pregnancy. Eur J Clin Pharmacol 44 (3):247-251. doi:10.1007/bf00271366

163. McGready R, Stepniewska K, Seaton E, Cho T, Cho D, Ginsberg A, Edstein MD, Ashley E, Looareesuwan S, White NJ, Nosten F (2003) Pregnancy and use of oral contraceptives reduces the biotransformation of proguanil to cycloguanil. Eur J Clin Pharmacol 59 (7):553-557. doi:10.1007/s00228-003-0651-x

164. Klier CM, Mossaheb N, Saria A, Schloegelhofer M, Zernig G (2007) Pharmacokinetics and elimination of quetiapine, venlafaxine, and trazodone during pregnancy and postpartum. Journal of clinical psychopharmacology 27 (6):720-722

165. Pinheiro EA, Wisner KL, Clark CT (2018) Quetiapine Dose Adjustments in Pregnant and Postpartum Women With Bipolar Disorder. J Clin Psychopharmacol 38 (1):89-91. doi:10.1097/JCP.0000000000000820

166. O'Hare MF, Leahey W, Murnaghan GA, McDevitt DG (1983) Pharmacokinetics of sotalol during pregnancy. Eur J Clin Pharmacol 24 (4):521-524. doi:10.1007/bf00609896

167. Oudijk MA, Ruskamp JM, Ververs FF, Ambachtsheer EB, Stoutenbeek P, Visser GH, Meijboom EJ (2003) Treatment of fetal tachycardia with sotalol: transplacental pharmacokinetics and pharmacodynamics. J Am Coll Cardiol 42 (4):765-770. doi:10.1016/s0735-1097(03)00779-4

168. Zheng S, Easterling TR, Umans JG, Miodovnik M, Calamia JC, Thummel KE, Shen DD, Davis CL, Hebert MF (2012) Pharmacokinetics of tacrolimus during pregnancy. Ther Drug Monit 34 (6):660-670. doi:10.1097/FTD.0b013e3182708edf

169. Bierhoff M, Smolders EJ, Tarning J, Burger DM, Spijker R, Rijken MJ, Angkurawaranon C, McGready R, White NJ, Nosten F, van Vugt M (2019) Pharmacokinetics of oral tenofovir disoproxil fumarate in pregnancy and lactation: a systematic review. Antivir Ther 24 (7):529-540. doi:10.3851/IMP3341

170. Benaboud S, Hirt D, Launay O, Pannier E, Firtion G, Rey E, Bouazza N, Foissac F, Chappuy H, Urien S, Treluyer JM (2012) Pregnancy-related effects on tenofovir pharmacokinetics: a population study with 186 women. Antimicrob Agents Chemother 56 (2):857-862. doi:10.1128/AAC.05244-11 171. Frederiksen MC, Ruo TI, Chow MJ, Atkinson AJ, Jr. (1986) Theophylline pharmacokinetics in pregnancy. Clin Pharmacol Ther 40 (3):321-328. doi:10.1038/clpt.1986.183 
172. Fauchet F, Treluyer JM, Valade E, Benaboud S, Pannier E, Firtion G, Foissac F, Bouazza N, Urien S, Hirt D (2014) Maternal and fetal zidovudine pharmacokinetics during pregnancy and labour: too high dose infused at labour? Br J Clin Pharmacol 78 (6):1387-1396. doi:10.1111/bcp.12459

173. O'Sullivan MJ, Boyer PJ, Scott GB, Parks WP, Weller S, Blum MR, Balsley J, Bryson YJ (1993) The pharmacokinetics and safety of zidovudine in the third trimester of pregnancy for women infected with human immunodeficiency virus and their infants: phase I acquired immunodeficiency syndrome clinical trials group study (protocol 082). Zidovudine Collaborative Working Group. Am J Obstet Gynecol 168 (5):1510-1516. doi:10.1016/s0002-9378(11)90791-1 


\section{Table}

Table 1. Examples of drugs that have been evaluated for PK changes and dose adjustment during pregnancy and their published pregnancy PBPK models

\begin{tabular}{|c|c|c|c|}
\hline \multirow{2}{*}{$\begin{array}{l}\text { Drug } \\
\text { (Major elimination } \\
\text { pathway) }\end{array}$} & \multicolumn{2}{|l|}{ Clinical Studies } & \multirow{2}{*}{$\begin{array}{l}\text { Aim of the published } \\
\text { Pregnancy PBPK model }\end{array}$} \\
\hline & Pregnant PK compared to non-pregnant women & Recommended action & \\
\hline Abacavir & $\begin{array}{l}\text { Similar PK parameters (AUC, Cmax, half-life) during } 3^{\text {rd }} \text { trimester to those at } \\
\text { postpartum }[80,81] \text {. }\end{array}$ & No dose adjustments are required. & NA \\
\hline $\begin{array}{l}\text { Acetaminophen } \\
\text { (Glucuronidation, } \\
\text { sulphation, P450) }\end{array}$ & $\begin{array}{l}\text { Half-life was significantly lower and CLpo (glucuronidation) was significantly } \\
\text { higher during }(8-12 \mathrm{GWs}) \text { compared to non-pregnant women [82]. } \\
\text { CLpo was } 58 \% \text { higher and half-life was } 28 \% \text { lower in pregnant }(31-38 \mathrm{GWs}) \\
\text { compared to non-pregnant women [83], CLpo (glucuronidation) increases at } \\
\text { delivery compared with non-pregnant women [84]. }\end{array}$ & $\begin{array}{l}\text { No dose changes due to increased } \\
\text { metabolite formation. }\end{array}$ & $\begin{array}{l}\text { Maternal and umbilical cord PK } \\
\text { prediction }[85]\end{array}$ \\
\hline $\begin{array}{l}\text { Acyclovir } \\
\text { (Renal) }\end{array}$ & Similar PK parameters at > $35 \mathrm{GWs}$ to those of non-pregnant adults $[86,87]$ & No dose changes. & $\begin{array}{l}\text { Maternal and umbilical cord PK } \\
\text { prediction [88] }\end{array}$ \\
\hline $\begin{array}{l}\text { Amoxicillin } \\
\text { (Renal) }\end{array}$ & $\begin{array}{l}\text { During } 2^{\text {nd }} \text { and } 3^{\text {rd }} \text { trimesters both renal CL (total) and renal CL (secretion) were } \\
\text { 1.6-fold higher than non-pregnant value [89]. }\end{array}$ & $\begin{array}{l}\text { Increase dose/more frequent dosing may } \\
\text { be needed [89]. }\end{array}$ & NA \\
\hline $\begin{array}{l}\text { Ampicillin } \\
\text { (Renal) }\end{array}$ & $\begin{array}{l}\text { Increased renal clearance, lower AUC and shorter half-life during } 3^{\text {rd }} \text { trimester } \\
{[90,91] .}\end{array}$ & Increase dose/more frequent dosing. & NA \\
\hline $\begin{array}{l}\text { Betamethasone } \\
\text { (Hepatic) }\end{array}$ & A 1.2-1.6 fold increase in clearance and volume of distribution [92]. & $\begin{array}{l}\text { Increase dosing frequency for sustained } \\
\text { plasma levels [93] or dosing per kg lean } \\
\text { body weight to reduce variability [92]. }\end{array}$ & Maternal PK prediction [94] \\
\hline $\begin{array}{l}\text { Buprenorphine } \\
\text { (CYP3A4, UGT1A1 } \\
\text { and UGT2B7) }\end{array}$ & Increasing CLpo and decreasing exposure during $18 \mathrm{GWs}$ to term $[17,95]$. & Increase dose. & Maternal PK prediction [96] \\
\hline $\begin{array}{l}\text { Caffeine } \\
\text { (CYP1A2) }\end{array}$ & Decreasing CLpo and increasing half-life with pregnancy progression [97,98]. & No (possible dose reduction). & Maternal PK prediction [99-102] \\
\hline $\begin{array}{l}\text { Cefazolin } \\
\text { (Renal) }\end{array}$ & About 1.7 -fold increase in systemic clearance during $18-33 \mathrm{GWs}[103,104]$. & Increase dose. & Maternal PK prediction [105] \\
\hline
\end{tabular}




\begin{tabular}{|c|c|c|c|}
\hline $\begin{array}{l}\text { Cefradine } \\
\text { (Renal) }\end{array}$ & $\begin{array}{l}\text { About } 1.6 \text {-fold increased clearance in systemic clearance during 10-29 GWs } \\
\text { [103]. }\end{array}$ & Increase dose [103]. & Maternal PK prediction [105] \\
\hline $\begin{array}{l}\text { Chloroquine } \\
\text { (CYP2C8, CYP3A } \\
\text { and CYP2D6) }\end{array}$ & $\begin{array}{l}\text { Chloroquine and its desethyl metabolite exposure were } 25 \% \text { and } 45 \% \text { lower during } \\
2^{\text {nd }} \text { and } 3^{\text {rd }} \text { trimesters [106]. Similar trend observed during } 2^{\text {nd }} \text { and } 3^{\text {rd }} \text { trimesters } \\
{[107] \text { and early } 3^{\text {rd }} \text { trimester [108]. This lower exposure was associated with } 34 \%} \\
\text { and } 80 \% \text { higher CLpo for chloroquine and its metabolite, respectively [106]. }\end{array}$ & $\begin{array}{l}\text { Dose increase may be desirable to achieve } \\
\text { similar exposure to non-pregnant women } \\
{[106] .}\end{array}$ & $\begin{array}{l}\text { PBPK evaluation during } \\
\text { pregnancy proposing dosing } \\
\text { regimens for prevention of Zika } \\
\text { Virus disease [54] }\end{array}$ \\
\hline $\begin{array}{l}\text { Clonidine } \\
\text { (Renal, CYP2D6) }\end{array}$ & About 1.8 -fold higher oral CL and shorter t1/2 [64]. & Dose increase/increase dosing frequency. & Maternal PK prediction [102] \\
\hline $\begin{array}{l}\text { Cyclosporine } \\
\text { (CYP3A4) }\end{array}$ & $\begin{array}{l}\text { Increased oral clearance, lower blood trough levels }(\mathrm{C} 0) \text { during } 2^{\text {nd }} \text { and } 3^{\text {rd }} \\
\text { trimesters. }\end{array}$ & $\begin{array}{l}\text { Daily dose increasing during pregnancy } \\
\text { [109]. }\end{array}$ & NA \\
\hline $\begin{array}{l}\text { Darunavir } \\
\text { (+ ritonavir) } \\
\text { (CYP3A4) }\end{array}$ & $\begin{array}{l}\text { Increased oral clearance during second (1.77-fold) and third trimester (2-fold). } \\
\text { Increasing darunavir dose from } 600 \mathrm{mg} \text { BID to } 800 \mathrm{mg} \text { BID failed to significantly } \\
\text { increase darunavir exposure [110]. }\end{array}$ & $\begin{array}{l}\text { Increasing dosing frequency [111] or } \\
\text { increasing ritonavir dose instead [110]. }\end{array}$ & $\begin{array}{l}\text { Maternal and umbilical cord PK } \\
\text { prediction }[78,79]\end{array}$ \\
\hline $\begin{array}{l}\text { Dextromethorphan } \\
\text { (CYP2D6, CYP3A4) }\end{array}$ & $\begin{array}{l}\text { CYP2D6 activity increased by } 25.6 \%, 34.8 \% \text { and } 47.8 \% \text { at } 14-18,24-28 \text {, and } 36- \\
40 \text { GWs. CYP3A activity increased by } 35 \%-38 \% \text { during all stages of the } \\
\text { pregnancy [24]. Metabolic ratio in extensive metabolizers were reduced by } 29 \% \\
\text { at } 36 \text { GWs [21]. }\end{array}$ & No recommendations. & Maternal PK prediction [102] \\
\hline $\begin{array}{l}\text { Diazepam } \\
\text { (CYP3A4 and } \\
\text { CYP2C19) }\end{array}$ & $\begin{array}{l}\text { CLpo at } 9-12 \text { GWs were within normal non-pregnant range [112]. Systemic } \\
\text { clearance was similar to non-pregnant women, while half-life was } 2 \text {-fold longer } \\
\text { [113]. }\end{array}$ & $\begin{array}{l}\text { No recommendation. Probably due to its } \\
\text { high transplacental passage, lower } \\
\text { effective dose is recommended to avoid } \\
\text { floppy infant syndrome[114]. }\end{array}$ & Maternal PK prediction [101] \\
\hline $\begin{array}{l}\text { Digoxin } \\
\text { (Renal) }\end{array}$ & $\begin{array}{l}\text { Lower exposure due to }(\sim 60 \%) \text { increase in renal CL during } 28-32 \mathrm{GWs}[15] \text { and } \\
\text { throughout third trimester [115]. }\end{array}$ & $\begin{array}{l}\text { An oral loading dose of } 0.5 \mathrm{mg} / 8 \mathrm{~h} \text { during } \\
24 \mathrm{~h} \text { followed by a maintenance regimen } \\
\text { of } 0.5 \mathrm{mg} / 12 \mathrm{~h} \text { been recommended to start } \\
\text { fetal supraventricular tachycardia } \\
\text { treatment [115]. }\end{array}$ & Maternal PK prediction [116] \\
\hline $\begin{array}{l}\text { Dolutegravir } \\
\text { (UGT1A1, } \\
\text { CYP3A4?) }\end{array}$ & $\begin{array}{l}\text { Slightly higher clearance, and lower AUCss. AUCss, maximum and trough } \\
\text { concentrations were } 20-50 \% \text { lower in the } 2^{\text {nd }} \text { and } 3^{\text {rd }} \text { trimesters compared to } \\
\text { postpartum }[117,118] .\end{array}$ & $\begin{array}{l}\text { No dose change was recommendation as } \\
\text { trough concentrations in pregnancy were } \\
\text { well above dolutegravir EC } 90 .\end{array}$ & $\begin{array}{l}\text { Maternal and umbilical cord PK } \\
\text { prediction [119] }\end{array}$ \\
\hline $\begin{array}{l}\text { Efavirenz } \\
\text { (CYP2B6) }\end{array}$ & $\begin{array}{l}\text { Similar PK during } 2^{\text {nd }} \text { and } 3^{\text {rd }} \text { trimesters to those observed in non-pregnant women } \\
{[120-122] .}\end{array}$ & No dose adjustment is required. & Maternal PK prediction [123] \\
\hline $\begin{array}{l}\text { Emtricitabine } \\
\text { (Renal) }\end{array}$ & $\begin{array}{l}\text { Higher CLpo, lower trough concentrations and exposure during } 2^{\text {nd }} \text { and } 3^{\text {rd }} \\
\text { trimesters compared to postpartum }[124,125] \text {. }\end{array}$ & $\begin{array}{l}\text { Observed changes were not sufficiently } \\
\text { large to warrant dose adjustment during } \\
\text { pregnancy. }\end{array}$ & $\begin{array}{l}\text { Maternal }[126,76,116,88] \text { and } \\
\text { umbilical vein }[76,88] \mathrm{PK} \\
\text { prediction. }\end{array}$ \\
\hline
\end{tabular}




\begin{tabular}{|c|c|c|c|}
\hline $\begin{array}{l}\text { Fluvoxamine } \\
\text { ( CYP2D6 and } \\
\text { CYP1A2) }\end{array}$ & $\begin{array}{l}\text { Therapeutic drug monitoring (TDM) data from pregnant women throughout } \\
\text { pregnancy showing about } 14 \%, 38 \% \text { and } 56 \% \text { decline in maternal drug serum } \\
\text { concentrations during } 1^{\text {st }}, 2^{\text {nd }} \text { and } 3^{\text {rd }} \text { trimesters, respectively compared to the non- } \\
\text { pregnant level [59]. }\end{array}$ & $\begin{array}{l}\text { Dose increase of about } 100 \% \text { during the } \\
\text { third trimester in order to maintain stable } \\
\text { concentrations [59]. }\end{array}$ & NA \\
\hline $\begin{array}{l}\text { Glyburide } \\
\text { (CYP3A4, } \\
\text { CYP2C9) }\end{array}$ & $\begin{array}{l}\text { CLpo was 2-fold higher during } 28-38 \text { GWs compared to non-pregnant value } \\
\text { [127]. }\end{array}$ & $\begin{array}{l}\text { Higher (double ?) doses may be needed } \\
\text { during pregnancy to achieve glycemic } \\
\text { control [127]. }\end{array}$ & Maternal PK prediction [128] \\
\hline $\begin{array}{l}\text { Imipenem } \\
\text { ( renal filtration and } \\
\text { dehydropeptidase ) }\end{array}$ & $\begin{array}{l}\text { Systemic CL increased by } 2.1 \text {, and } 2.9 \text {-fold at } 7-11 \text { GWs and } 37-41 \mathrm{GWs} \text {, } \\
\text { respectively compare to non-pregnant women. Similarly, renal CL increased by } \\
2.4 \text { and } 2.7 \text { fold, while Cmax reduced by } 2.93 \text { and } 2.89 \text { fold at at } 7-11 \mathrm{GWs} \text { and } \\
37-41 \mathrm{GWs} \text {, respectively [129]. }\end{array}$ & $\begin{array}{l}\text { Adjustment of doses of imipenem may be } \\
\text { required. }\end{array}$ & NA \\
\hline ( CYP3A4) & $\begin{array}{l}\text { CLpo was 2-fold higher, AUC was } 1.2 \text {-fold lower and Cmax was } 1.7 \text {-fold lower } \\
\text { than postpartum values [130]. CLpo increased and AUC decreased by } 3.7 \text {-fold } \\
\text { compared with postpartum [131]. }\end{array}$ & $\begin{array}{l}\text { An increased dose of indinavir during } \\
\text { pregnancy may be preferable to ensure } \\
\text { adequate exposure throughout pregnancy } \\
{[130] \text {. }}\end{array}$ & Maternal PK prediction [132] \\
\hline $\begin{array}{l}\text { Indomethacin } \\
\text { (Renal, bile, } \\
\text { UGT?) }\end{array}$ & CLpo was 2.2-fold higher during 12-31 GWs than in healthy male subjects [133]. & Possible dose adjustment. & Maternal PK prediction [134] \\
\hline $\begin{array}{l}\text { Labetalol } \\
\text { ( UGT1A1 and } \\
\text { UGT2B7) }\end{array}$ & $\begin{array}{l}\text { Increasing CLpo with pregnancy progression from } 1.4 \text {-fold at } 12 \mathrm{GWs} \text { to } 1.6 \text {-fold } \\
\text { at } 40 \mathrm{GWs} \text { [135]. }\end{array}$ & $\begin{array}{l}\text { Dose increase/increase dosing frequency } \\
{[135] .}\end{array}$ & NA \\
\hline $\begin{array}{l}\text { Lamivudine } \\
\text { (Renal) }\end{array}$ & $\begin{array}{l}\text { About } 22 \% \text { increase in CLpo between } 6 \text { and } 39 \text { GWs compared with non-pregnant } \\
\text { CLpo [136]. }\end{array}$ & No need for dose adjustment. & Maternal PK prediction [126] \\
\hline $\begin{array}{l}\text { Metformin } \\
\text { (Renal) }\end{array}$ & $\begin{array}{l}\text { Similar pharmacokinetic parameters during } 10-14 \mathrm{GWs} \text {, increased renal clearance } \\
\text { by } 1.5 \text {-fold at } 22-26 \mathrm{GWs} \text { and by } 1.3 \text {-fold at } 34-38 \mathrm{GWs} \text {. Secretion clearance } \\
\text { increased by } 1.5 \text {-fold at } 22-26 \mathrm{GWs} \text { and by } 1.3 \text {-fold } 34-38 \mathrm{GWs}[137] \text {. } \\
\text { At } 26-38 \mathrm{GW} \text {, bioavailability increased by } 1.35 \text {-fold, } 1.6 \text {-fold increase in renal CL, } \\
\text { and } 1.7 \text {-fold increase in secretion CL, with no significant change to half-life after } \\
500 \mathrm{mg} \text { dose. These fold changes were minimal for the } 1000 \mathrm{mg} \text { dose [138]. }\end{array}$ & Dose increase maybe required. & Maternal PK prediction $[139,116]$ \\
\hline $\begin{array}{l}\text { Methadone } \\
\text { (CYP3A4, CYP2B } \\
\text { and renal) }\end{array}$ & $\begin{array}{l}\text { Increase clearance during } 1^{\text {st }} \text {, second and third trimesters and lower trough } \\
\text { concentrations despite the dose were higher during pregnancy compared with } \\
\text { postpartum [140]. Higher unbound clearance and lower trough concentrations } \\
\text { during pregnancy compared with non-pregnant women [141]. Half-life was } 60 \% \\
\text { shorter than non-pregnant [142]. }\end{array}$ & $\begin{array}{l}\text { Increase dose[141], dosing frequency } \\
\text { [143] to reduce fetal stress. About } 86 \% \text { of } \\
\text { pregnant women required increasing } \\
\text { maintenance dose [144]. }\end{array}$ & Maternal PK prediction [128] \\
\hline
\end{tabular}




\begin{tabular}{|c|c|c|c|}
\hline $\begin{array}{l}\text { Metoprolol } \\
\text { ( CYP2D6, } \\
\text { CYP3A4 and } \\
\text { Renal) } \\
\end{array}$ & $\begin{array}{l}\text { CLpo was about } 4.4 \text { times higher during } 35-38 \mathrm{GW} \text { and the exposure exceeded } \\
\text { that after pregnancy by a factor of } 2 \text { to } 13 \text { [145,146]. About } 4 \text {-fold lower exposure } \\
\text { during } 34-39 \mathrm{GWs} \text { compared with postpartum exposure[147]. CLpo was } 1.8 \text {-fold } \\
\text { and } 3.0 \text {-fold higher at } 22-26 \text { and } 34-38 \mathrm{GWs} \text {, respectively compared with } \\
\text { postpartum clearance, while renal CL was } 1.5 \text {-fold higher during } 34-38 \mathrm{GWs}[23] \text {. }\end{array}$ & Dose increase/increase dosing frequency. & $\begin{array}{l}\text { Maternal PK prediction } \\
{[99,101,102]}\end{array}$ \\
\hline $\begin{array}{l}\text { Midazolam } \\
\text { (CYP3A4) }\end{array}$ & $\begin{array}{l}\text { CLpo increased by } 2 \text {-fold during } 28-32 \mathrm{GWs} \text {, the exposure reduced by } 46 \% \text { and } \\
\text { Cmax was } 28 \% \text { lower of postpartum values, while no change to the half-life [15]. }\end{array}$ & $\begin{array}{l}\text { Many need dose increase during second } \\
\text { half of pregnancy [15]. }\end{array}$ & $\begin{array}{l}\text { Maternal } \\
{[99,148,116,101,36,149,132] \text { and }} \\
\text { umbilical cord [36] PK prediction }\end{array}$ \\
\hline $\begin{array}{l}\text { Morphine } \\
\text { (UGT) }\end{array}$ & $\begin{array}{l}\text { Average half-life was } 0.5 \text {-fold shorter and CLpo was } 1.7 \text {-fold higher, while } \\
\text { distribution volume did not change in parturients than in the non-pregnant } \\
\text { women[150]. }\end{array}$ & Possible dose increase. & NA \\
\hline $\begin{array}{l}\text { Nevirapine } \\
\text { ( CYP2B6, } \\
\text { CYP3A4) }\end{array}$ & $\begin{array}{l}\text { CLpo was } 22 \% \text { higher, while exposure, Cmin and Cmax were } 19.2 \%, 18.6 \% \text {, and } \\
28.5 \% \text { lower, respectively during pregnancy[30]. Increased CLpo by } 30 \% \text { during } \\
33-42 \mathrm{GWs}[31] . \text { No significant changes in PK parameters (AUC and CLpo) during } \\
2^{\text {nd }} \text { and } 3^{\text {rd }} \text { trimesters vs postpartum[151]. PK parameters (C12h, Cmax AUC) } \\
\text { were lower during } 3^{\text {rd }} \text { trimester compared to postpartum [152]. }\end{array}$ & $\begin{array}{l}\text { Possible dose optimization based on } \\
\text { CYP2B6 phenotypes. }\end{array}$ & $\begin{array}{l}\text { Maternal and umbilical cord PK } \\
\text { prediction [77] }\end{array}$ \\
\hline $\begin{array}{l}\text { Nifedipine } \\
\text { (CYP3A4) }\end{array}$ & $\begin{array}{l}\text { Approximately 2-fold lower Cmax and 2.73-fold increase in CLpo during 26-35 } \\
\text { GWs [153] compared to non-pregnant women [154] and 2.4-fold at labour [29]. }\end{array}$ & $\begin{array}{l}\text { Dose increase/increase dosing frequency } \\
{[153] .}\end{array}$ & Maternal PK prediction $[101,132]$ \\
\hline $\begin{array}{l}\text { Oseltamivir } \\
\text { carboxylate } \\
\text { ( renal ) }\end{array}$ & $\begin{array}{l}\text { The systemic exposure of oseltamivir carboxylate }(\mathrm{OC}) \text { was reduced } \\
\text { approximately } 30 \% \text { and CLpo increased by } 40 \% \text { in pregnant women }[35,155] \text {. The } \\
\text { CLpo was approximately } 66 \%, 45 \% \text { and } 28 \% \text { higher during } 1^{\text {st }}, 2^{\text {nd }} \text { and } 3^{\text {rd }} \\
\text { trimesters, respectively compared with CLpo in non-pregnant women. Half-life of } \\
\text { OC was not different between pregnant and non-pregnant women [35]. }\end{array}$ & $\begin{array}{l}\text { Increasing the dose and/or dosing } \\
\text { frequency of oseltamivir during pregnancy } \\
\text { may be necessary to achieve comparable } \\
\text { exposure in pregnant and nonpregnant } \\
\text { women }[35,155] \text {. }\end{array}$ & Maternal PK prediction [139] \\
\hline $\begin{array}{l}\text { Paroxetine } \\
\text { (CYP2D6) }\end{array}$ & $\begin{array}{l}\text { There was a drop of } 12 \%, 34 \% \text { and } 51 \% \text { of the plasma levels during } 1^{\text {st }}, 2^{\text {nd }} \text { and } \\
3^{\text {rd }} \text { trimesters compared to the baseline [59]. }\end{array}$ & $\begin{array}{l}\text { Dose increase of about } 100 \% \text { during the } \\
\text { third trimester in order to maintain stable } \\
\text { concentrations [59]. }\end{array}$ & Maternal PK prediction [102] \\
\hline $\begin{array}{l}\text { Phenytoin } \\
\text { (CYP2C9) }\end{array}$ & $\begin{array}{l}\text { Phenytoin CLpo increased during pregnancy by } 1.9,2.0 \text {, and } 2.2 \text {-fold during } 1^{\text {st }} \\
2^{\text {nd }} \text { and } 3^{\text {rd }} \text { trimesters compared to postpartum women }[156] \text {. Both total and free } \\
\text { concentration decreased, while free fraction increased with pregnancy progression } \\
{[156,157] \text {. }}\end{array}$ & $\begin{array}{l}\text { Dose increased during pregnancies to } \\
\text { maintain therapeutic efficacy }[158,159] \text {. }\end{array}$ & Maternal PK prediction [128] \\
\hline Piperacillin & $\begin{array}{l}\text { Cmax was 2-fold lower and systemic CL was } 2.8 \text { higher near term compared with } \\
\text { non-pregnant patients [160]. }\end{array}$ & Dose increase. & NA \\
\hline Piperaquine & $\begin{array}{l}\text { Similar PK parameters during } 2^{\text {nd }} \text { and } 3^{\text {rd }} \text { trimesters to those observed in } \\
\text { nonpregnant women }[34,161] \text {. }\end{array}$ & No need for dose adjustment. & $\begin{array}{l}\text { Evaluation of the impact of HIV } \\
\text { mediated drug-drug interactions }\end{array}$ \\
\hline
\end{tabular}




\begin{tabular}{|c|c|c|c|}
\hline (CYP3A4) & & & $\begin{array}{l}\text { on piperaquine PKs during } \\
\text { pregnancy in different ethnic } \\
\text { populations [57] }\end{array}$ \\
\hline $\begin{array}{l}\text { Proguanil } \\
\text { ( CYP2C19) }\end{array}$ & $\begin{array}{l}\text { Reduced formation of cycloguanil metabolite via CYP2C19. Mean cycloguanil } \\
\text { Cmax in blood and in plasma at }>36 \mathrm{GWs} \text { were } 50 \% \text { lower compared with Cmax } \\
\text { after pregnancy [162]. Median dose-adjusted concentration of cycloguanil was } \\
73 \% \text { lower during 3rd trimester compared with postpartum level [163]. }\end{array}$ & $\begin{array}{l}\text { Dose of proguanil should be increased by } \\
50 \%[163] .\end{array}$ & NA \\
\hline $\begin{array}{l}\text { Quetiapine } \\
\text { (CYP3A4) }\end{array}$ & $\begin{array}{l}\text { Increased CLpo [127]. AUC decreased by } 27 \%, 42 \% \text { and } 18 \% \text { during } 1^{\text {st }}, 2^{\text {nd }} \text { and } \\
3^{\text {rd }} \text { trimesters, respectively compared with postpartum[164]. }\end{array}$ & Dose increasing [165]. & Dosing optimisation strategy [49] \\
\hline $\begin{array}{l}\text { Sotalol } \\
\text { ( Renal ) }\end{array}$ & $\begin{array}{l}\text { Systemic CL and CLpo were } 1.6 \text {-and } 1.8 \text {-fold higher during } 32-36 \mathrm{GWs} \text { compared } \\
\text { to postpartum. Bioavailability and elimination rate were similar in these two } \\
\text { occasions [166]. }\end{array}$ & Possible dose adjustment [167]. & NA \\
\hline $\begin{array}{l}\text { Tacrolimus } \\
\text { ( CYP3A4) }\end{array}$ & $\begin{array}{l}\text { About } 39 \% \text { higher clearance during mid- and late-pregnancy compared to } \\
\text { postpartum [168] }\end{array}$ & Dose increase [168]. & Maternal PK prediction [139] \\
\hline $\begin{array}{l}\text { Tenofovir } \\
\text { ( Renal ) }\end{array}$ & $\begin{array}{l}\text { Slight reduction in systemic exposure and trough concentration during the } 2^{\text {nd }} \text { and } \\
3^{\text {rd }} \text { trimesters [169]. Pregnant women had a } 39 \% \text { higher apparent clearance } \\
\text { compared to non-pregnant women [170]. }\end{array}$ & $\begin{array}{l}\text { Dose increasing from second trimester to } \\
\text { delivery [170]. }\end{array}$ & {$[126,76]$} \\
\hline $\begin{array}{l}\text { Theophylline } \\
\text { ( CYP1A2, Renal ) }\end{array}$ & $\begin{array}{l}\text { Free CLpo decreased by } 1.2 \text { and } 1.4 \text {-fold during } 24-26 \text { and } 36-38 \text { GWs, } \\
\text { respectively. non-renal CL decreased by } 1.6 \text {-fold at } 36-38 \text { GWs, while most } \\
\text { increase in renal CL was } 1.8 \text {-fold at } 24-26 \text { GWs [171]. CLpo was } 20-53 \% \text { lower } \\
\text { during last few weeks of pregnancy [26]. }\end{array}$ & $\begin{array}{l}\text { Possible dose reduction might be required } \\
\text { during the second half of pregnancy, } \\
\text { especially for renal impairment women, } \\
\text { due to the narrow therapeutic window. }\end{array}$ & $\begin{array}{l}\text { Maternal }[36,102] \text { and umbilical } \\
\text { cord [36] PK prediction }\end{array}$ \\
\hline $\begin{array}{l}\text { Zidovudine } \\
\text { ( UGT2B7, Renal) }\end{array}$ & $\begin{array}{l}\text { No change in the PK parameters during } 2^{\text {nd }} \text {, and } 3^{\text {rd }} \text { trimesters and at delivery } \\
\text { compared to non-pregnant women }[172,173] \text {. }\end{array}$ & No change to the dose. & $\begin{array}{l}\text { Maternal and umbilical cord PK } \\
\text { prediction [36] }\end{array}$ \\
\hline
\end{tabular}




\section{Figure Legends}

Fig 1 Examples of longitudinal variation in different physiological parameters during normal gestation (for more details see [10]). (A) Fold-change in CYP isozyme expression compared to non-pregnant subjects for 3A4, 2D6 and 1A4; (B) Changes in human serum albumin (red line, left y-axis) and $\alpha 1$-acid glycoprotein (green line, right y-axis); (C) Changes in cardiac output (red line) or glomerular filtration rate (GFR) (black line) and (D) changes in plasma volume (black line) or feto-placental unit (red line).

Fig 2 Pregnancy PBPK model input and output components

Fig 3 The impact of gestation on the fraction of chloroquine metabolized by CYP isozymes. Chloroquine metabolism is represented during dosing over 40 weeks of gestation by the fraction metabolism by each CYP isozyme (fmCYP) responsible for chloroquine metabolism, namely CYP 2C8, 2D6 and 3A4 [54]. 